Original research article

\title{
Investigating networks of corporate influence on government decision-making: The case of Australia's climate change and energy policies
}

\author{
Adam Lucas \\ School of Humanities and Social Inquiry, University of Wollongong, Wollongong, New South Wales 2522, Australia
}

\section{A R T I C L E I N F O}

\section{Keywords:}

Energy policy

Fossil fuels

Decarbonisation

Corporate power

Covert networks

\begin{abstract}
A B S T R A C T
This paper argues that the ability of dominant corporations in the fossil fuel and other polluting industries to shape government policy on climate change and energy issues is directly related to their financial interests in particular countries, and emblematic of the crippling effect which they have exercised on the ability of nation states to decarbonise. Using Australia as an exemplar of the many favourable policy outcomes which powerful corporate interests have secured from successive governments in relation to climate and energy policy, it seeks to demonstrate that covert networks of political influence have played a major role in the decisions made and actions implemented in both areas of policymaking over the last fifteen years. Through detailed empirical analysis of a database of current and former senior politicians, political staffers and bureaucrats with employment links to the fossil fuel and resource extraction industries, it argues that these industries have constructed a covert network of lobbyists and revolving door appointments which has ensured that industry interests continue to dominate Australia's energy policy, and that its emissions from fossil fuel use continue to rise. Covert corporate influence in Australia's energy and resource sectors provides an additional layer of explanation for the persistence of structural biases in its financing, policy and regulatory regimes to those accounts which draw on different forms of discourse and policy analysis.
\end{abstract}

\section{Introduction}

The maintenance of cheap, easily transportable supplies of fossil fuels has been crucial to the global expansion of corporate power, and the geopolitical dominance of those countries in which the wealthiest corporations are headquartered [1-3]. A handful of public and private corporations dominate the oil, coal and gas sectors and electricity supply in most of these countries. However, because fossil fuel use is responsible for roughly 60 percent of historic greenhouse gas emissions [4: 158-159; 5: 36-7; 6] and more than 65 percent of current emissions [7], those corporations with significant investments in the extraction, distribution and consumption of fossil fuels have a strong financial and political incentive to undermine global efforts to reduce the carbon intensity of the energy sector. They are primarily dependent for their asset values on the future viability of fossil fuels as the world's primary energy source, and have understandably become increasingly preoccupied with ensuring that dependency is maintained as threats to their hegemony have grown.

Since the late 1980s, when global attention began to be focused on climate change issues, interest coalitions formed by highly capitalized fossil fuel and other carbon-intensive businesses and industries have actively sought to sow the seeds of confusion with respect to the implications of climate science research, and to oppose any climate or energy policy proposals which threaten their incumbency [8-19]. Such fossil-fuelled interest coalitions have been most intensively studied in the United States and Canada, where their influence has become so pervasive they can be characterized as constituting a new social movement. The climate change counter-movement (CCCM) in both countries consists of polluting businesses and industries, together with the peak bodies, think tanks, publishers, media outlets, politicians, political parties, scientists, economists and engineers they have cultivated and patronised. The politics of CCCM constituents tend to range from conservative to reactionary, while most of its tactics have been borrowed from Big Tobacco and the public relations industry $[14,20,21]$.

Recent research into the CCCM in the US and Canada has clearly revealed the pervasive and disproportionate influence of fossil energy and resource corporations on climate change and energy politics in two of the world's most politically and economically powerful developed countries [22-28]. This paper contributes to North American CCCM research as a comparative study of similar processes in Australia. It also

E-mail address: alucas@uow.edu.au. 
contributes to recent research in science and technology studies, innovation studies and sustainable energy transitions by documenting some of the covert strategies used by powerful corporate interests to dominate government climate and energy policy, weaken regulatory oversight, and entrench their incumbency [29-33]. It builds upon a considerable body of research by investigative journalists and environmental and social justice advocates for its empirical data. Its theoretical and interpretive schema is derived from the research of scholars in critical political economy, policy studies, and environmental sociology and politics.

The paper's central thesis is that covert networks of political influence have been carefully constructed over many years by the fossil fuel and resource extraction industries to further their own political and financial interests: for several decades they have largely determined the decisions made and actions taken by successive Australian governments in relation to climate change and energy policy. These networks of influence are covert in the sense that they are not officially documented, and the individuals involved do not acknowledge their existence. However, it is possible to discern their existence and map their activities using a range of unconventional sources. The methods developed and conclusions drawn in this paper add a structural and instrumental power dimension to accounts which draw on different forms of discourse and policy analysis. Clearly, covert and other undocumented forms of political activity cannot be subjected to discursive forms of analysis or any form of critical theoretical and methodological inquiry unless those activities can somehow be documented or inferred from their outcomes.

The paper begins therefore with an outline of the broader context of bipartisan political support for the further expansion of fossil fuel production in Australia, and the policy outcomes which are the consequences of that support. It outlines twenty-four areas of policy- and decision-making that indicate the entrenchment of structural biases in the financing, policy and regulatory regimes governing fossil fuel use and resource extraction in Australia. It seeks to demonstrate that neither the shared Promethean narrative of political and economic elites, nor a shared government-industry discourse focused on protecting Australia's industrial competitiveness convincingly explain these outcomes [34-36]. It argues, to the contrary, that these policy outcomes are strong indicators of corporate state capture by the fossil fuel and resource extraction industries. Because corporate state capture involves situations in which 'private interests subvert legitimate channels of political influence and shape the rules of the legislative and institutional game through private payments to public officials' [37, cf. 38], it provides a plausible working hypothesis to explain these policy outcomes. With respect to the kinds of theoretical approaches that can usefully be deployed to understand how certain commercial and political interests are able to entrench their dominance over governments, rivals and opponents, the paper draws on theories of biased pluralism, economic-elite domination, para-politics and capital as power [39-47]. These theoretical approaches arguably provide compelling explanations of the otherwise inexplicable policy outcomes we have witnessed in Australia over the last three decades with respect to climate change and energy policy.

The methodological approach which the paper develops attempts to provide empirical support for the theoretical conclusions drawn. In order to demonstrate the breadth and depth of corporate influence on government policy- and decision-making with respect to energy and climate policy, it combines empirical evidence compiled by fellow researchers on corporate tax avoidance, lobbying, political donations and subsidies with my own research on lobbying and revolving door appointments. It draws on the employment histories and responsibilities of 160 individuals who have worked or are currently working for both government and industry in the fossil energy and resource portfolios since 2007. A reasonable inference from this evidence is that a significant number of politicians, political staffers and senior bureaucrats have enabled the interests of the fossil energy and resource sectors to continue to dominate energy policies nationally and in two of the most populous states, even though it is clear that the country's international obligations require it to decarbonise by 2050 and the majority of Australians support that goal. In the absence of juridical procedures which might establish that these correlations indicate various levels of causation, it is inferred from the evidence presented that major coal, oil and gas corporations operating in Australia have not only increased their efforts over the last decade or so to ensure that fossil fuel export and use is supported by any elected government for the foreseeable future, they have been largely successful in achieving their goals across multiple areas of policy- and decision-making.

\section{The policy context: bipartisan support for the expansion of Australia's fossil fuel industry}

Ever since the first Australian colonies were granted self-rule by the British government in the mid-nineteenth century, the colonies' political and administrative elites have supported the largely unconstrained exploitation of the continent's diverse and extensive natural resources. Soon after Federation in 1901, and especially during the post-War period, the country's mining and fossil energy sectors underwent rapid expansion, much of which was financed or underwritten by state and federal governments. Bipartisan support for this expansion from both the Australian Labor Party (ALP) and the Coalition of the Liberal and National parties was so consistent that the country acquired the epithet 'Quarry Australia' in the early 1980s [48]. ${ }^{1}$ At the core of this political consensus, particularly since the early 1980s, has been a commitment from both parties to prevent the introduction of any policy measures which 'have net adverse economic impacts nationally or on Australia's trade competitiveness' [49, cf. 36]. This commitment has become more obvious over the last decade or so as Australian citizens and their leaders have been forced to confront the fact that the country's continued reliance on fossil resource extraction to stimulate its economy is both contributing to and exacerbating dangerous climate change, including the increasing frequency and intensity of extreme weather events throughout the country.

Growing recognition of the dangers associated with continued fossil fuel use has fractured Australia's long-standing political consensus in support of a fossil-fuelled future. As the economics of renewables have improved to the point that they are now the cheaper alternative, deep rifts have emerged within and between the ALP and the Coalition. For the last several years, the installation and running costs for renewables have been lower than those of fossil-fuelled incumbents in Australia and the majority of its fossil export destinations [50,51]. Tasmania, South Australia and the Australian Capital Territory (ACT) have made significant inroads into decarbonising their electricity supplies, while more than three million Australian households and businesses have installed more than $13.4 \mathrm{GW}$ of solar photovoltaic capacity since 2010 [52]. In 2020, South Australia drew almost 60 percent of its electricity from renewables, Tasmania 99 percent, and the ACT, 100 percent. However, this only covers around 11 percent of the Australian population. The states of New South Wales (NSW), Victoria, Queensland and Western Australia (WA) have made far less progress, with Victoria at 28 percent, WA at 24 percent, NSW at 21 percent, and Queensland at 17 percent [52-54].

Although these changes are clearly significant, almost $82 \%$ of Australia's domestic emissions are still generated by electricity, stationary

\footnotetext{
1 The National Party was formerly known as the Country Party (1913-1975). The Liberal and National parties and their predecessors have been in various coalitions since the 1920s, and are today described as a 'centre right' coalition, while the ALP is described as 'centre left'. Both the Coalition and the ALP have implemented neoliberal policies over the last four decades. However, there are 'hard right' (or 'far right') factions in all three parties, and their influence within those parties has become stronger in recent decades, whether or not the individuals involved self-identify as belonging to the relevant factions.
} 
energy (excluding electricity), transport and fugitive emissions [55]. Australia remains one of the most carbon-intensive economies on earth, and will almost certainly fail to meet its current international obligations to reduce its carbon emissions unless it is able to end the fossilfuelled dominance of its climate and energy policies. More than 96 percent of the country's transport fuels and 85 percent of its electricity were generated from fossil fuels in 2017 [56: 11-14]. While those figures have markedly improved for electricity generation over the last few years, moving from almost $24 \%$ of all electricity coming from renewable sources in 2019 to almost 28 percent in 2020 [52], they have not improved for transport. Furthermore, despite the growth in the quantity of renewable energy being generated, it has had comparatively little effect on the overall proportion of Australia's emissions generated by fossil fuels. In 2008, that figure was 72 percent; in 2016-17, it was 71 percent $[57: 62,56: 8]$. Australia's domestic emissions are due to fall by more than 8 percent in 2020 due to COVID [58], but that is still less than the level of annual emission reductions currently required by all developed countries to meet the Paris Agreement targets for 2030 $[59,60] .^{2}$ According to energy analyst Hugh Saddler, a 5 percent reduction in 2020 transport emissions is attributable to COVID, while electricity sourced from fossil fuels fell below 74 percent of total generation last year, partially due to COVID but more so the increased renewable electricity capacity coming online [53].

The Federal Government's own figures nevertheless demonstrate that between 1990 and 2018, emissions from fossil electricity generation increased by more than 47 percent, and from transport by more than 57 percent [61]. Prior to the COVID pandemic in December 2019, Australia's transport emissions had increased 63 percent relative to 1990 levels, its fugitive emissions by 51 percent, its stationary energy emissions (excluding electricity) by 54 percent, and its emissions from industrial processes and product use by 35 percent. Relative to 1990, its total electricity emissions increased by 'only' 34 percent due to the rapid growth in wind and solar capacity at the state and territory level since 2016, and the inclusion of the renewable offset in the final figure [62: 8, 45]. The fact that Australia's domestic emissions have continued to grow over the last three decades is an important sign of the fossil fuel industry's success in resisting substantive policy changes across multiple economic sectors, and is arguably a strong indicator of corporate state capture.

The states and territories with the largest economically exploitable coal and gas reserves remain the regions with the largest dependencies on fossil fuels for energy consumption and export revenue, i.e. NSW, WA, Queensland and the Northern Territory (NT). They have also been the slowest to decarbonise, even though they also have excellent renewable energy resources and are home to many large businesses that support an energy transition $[63,64]$. However, given the economic value of their fossil fuel reserves to the industry, and the rapidity with which renewables are displacing their domestic markets for energy supply, it is in these jurisdictions that the hegemony of fossil-fuelled interests are the most threatened. Consequently, it is in these jurisdictions and at the federal level that the industry has been the most proactive in ensuring its interests are maintained.

One of the areas in which the industry has been particularly proactive is ensuring the maintenance and expansion of a range of direct and indirect subsidies from state and federal governments. More than \$12 billion of taxpayer funds flow annually to the industry in direct subsidies [65], amounting to more than $\$ 70$ billion between 2015 and 2021 (Fig. 1). Estimates of the combined costs of subsidies and the social and environmental externalities produced by carbon pollution in Australia range from around $\$ 18$ billion to $\$ 39$ billion annually in current

\footnotetext{
2 If the current Federal Coalition Government's dedication to a 'gas-led recovery' is realized (Murphy 2020a; Foley 2020), it is very unlikely that it will even be able to maintain its current inadequate emission reductions targets post-COVID.
}

Australian dollars [57: 60, 66: 35]. The financing of fossil fuel infrastructure and maintenance are two other areas in which state and federal governments continue to be involved (Tables 1 and 2). Shortly after the Coalition regained power federally in September 2013, it committed more than $\$ 3$ billion in funding for 'low emission' projects and fossil fuel exploration. It also provided $\$ 526$ million in public finance to expand the country's coal, oil and gas production, while the WA, NSW and Queensland governments provided $\$ 2.87$ billion over the same two-year period in capital injection for state-owned electricity companies and port infrastructure [67].

The Federal Coalition's unwavering dedication to subsidising fossil fuels became even more apparent in its 2021 Federal Budget. It will provide $\$ 2$ billion to ensure that Australia's only two remaining oil refineries remain open [68], another $\$ 600$ million for a new gas-fired power station in NSW that the private sector and the national energy regulator has rejected as unnecessary [69], \$264 million for carboncapture-and-storage (CCS) research, and a further \$59 million for new gas projects [70]. It is noteworthy that more than $\$ 3.5$ billion has already been committed to CCS technology since 2003, although successive governments were only able to spend $\$ 1.3$ billion of that funding up to 2017 due to a lack of projects and support from industry [71].

The fact that both the ALP and Coalition have provided billions of dollars in subsidies to one of the most profitable industries on Earth, and continue to do so, provides a second indicator of corporate state capture.

Bearing in mind that Australia's superannuation funds operate under investment rules regulated by the Federal Government, those funds also continue to invest billions of dollars into fossil fuel projects, despite growing calls for disinvestment from members [72]. The industry's success in ensuring it is under no pressure from government regulators to minimize its exposure to carbon risk in the face of growing domestic and international pressure provides a third indicator of corporate state capture.

Several powerful factions within the ALP and Coalition have repeatedly made it clear that they regard any kind of renewable energy transition as a threat to the existence of their political and economic allegiances with workers in the fossil fuel industry and major corporations in finance, energy and resources. A number of individuals within these factions have consistently sought to undermine any claims that fossil-fuelled development is no longer economically, socially or environmentally desirable. They continue to support and promote the fossil fuel industry's strategy of locking in as much expansion as possible, as quickly as possible, while simultaneously ensuring that it is able to minimize its financial and legal obligations to any of the regions and populations in which it operates. Consequently, over the last three decades, Australian coal production has tripled while its natural gas production has quintupled [56: 8, 13]. Between the early 1980s and the early 2010s, Australia was the world's largest coal exporter, and has recently regained that mantle [57,73]. It has also recently overtaken Qatar as the world's largest exporter of natural gas [74,75].

Such rapid expansion and market dominance is a fourth indicator of corporate state capture by this fossil-fuelled interest coalition, a point well-illustrated by the enormous revenues generated by Australian coal and gas exports, which are second only to iron ore. The whole sector generated almost $\$ 115$ billion in export revenue from its Australian operations in $2019 / 20$, slightly less than the record $\$ 132$ billion it generated in 2018/19. To put these figures into perspective, Australia's GDP in $2019 / 20$ was $\$ 1985$ billion, indicating that the industry contributed around 6 percent of GDP that financial year and around 30 percent of all export revenue in 2019/20. Over the fifteen year period between 2005 and 2020, by far the largest fossil export earner was coal, totalling more than $\$ 643$ billion, with gas generating $\$ 287$ billion and petroleum more than $\$ 166$ billion over the same period [76]. As a percentage of nominal GDP, the last few years have seen record levels of coal export revenue, comparable only to the recent boom years from 2008 to 2012 [57,77]. Export revenues from gas are historically unprecedented (Fig. 2). 


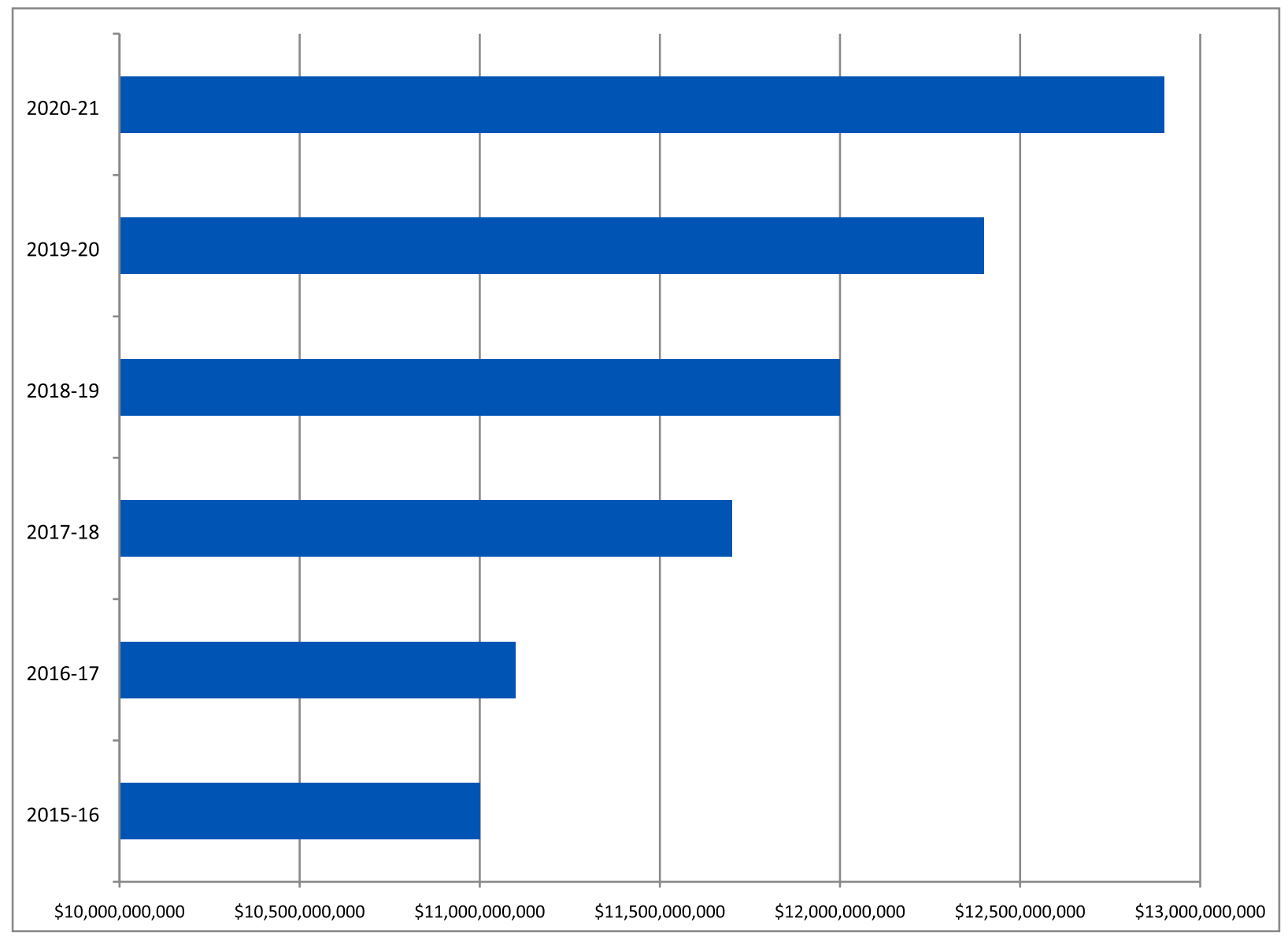

Fig. 1. Australian government direct subsidies paid to the fossil fuel industry, 2015-2021. Source: Market Forces (2020).

Table 1

Australian state and federal bodies providing financial support for the fossil fuel industry, 2013-14. Source: Makhijani \& Doukas (2014).

\begin{tabular}{|c|c|c|}
\hline GOVT ENTITY & STATE SUPPORT & \$ AMOUNT \\
\hline \multirow{4}{*}{$\begin{array}{l}\text { Fed Dept of Industry, Innovation \& Science } \\
\text { (total budgeted program expend.) }\end{array}$} & Low Emission Technologies for Fossil Fuels Program & $\$ 500 \mathrm{~m}$ \\
\hline & Carbon Capture \& Storage Flagships Program & $\$ 2000 \mathrm{~m}$ \\
\hline & Low Emission Technologies Demonstration Fund & $\$ 410 m$ \\
\hline & Coal Mining Abatement Technology Support Program & $\$ 70 m$ \\
\hline Geoscience Australia & Fossil fuel exploration, esp. offshore reserve development. & $\$ 33 \mathrm{~m}$ \\
\hline TOTAL FEDERAL SUPPORT & & \$3013 million \\
\hline WA Govt & Govt capital injections to state-owned electricity companies & $\$ 219 \mathrm{~m}$ \\
\hline QLD Govt & Govt capital injections to state-owned electricity companies & $\$ 256 \mathrm{~m}$ \\
\hline QLD Govt & Govt capital injections to support port infrastructure & $\$ 2200 \mathrm{~m}$ \\
\hline NSW Govt & Govt capital injections to support port infrastructure (Port Kembla) & $\$ 197 \mathrm{~m}$ \\
\hline TOTAL STATE SUPPORT & & \$2872 million \\
\hline
\end{tabular}

However, if we examine this expansion from a climate risk management perspective, these developments look far less defensible. Australia's annual contribution to atmospheric GHG emissions rises to around 5.5 percent of the global burden if its domestic emissions are combined with those from its exports [78]. Given that Australians constitute 0.32 percent of the world's population, its residents might only be responsible for 0.25 percent of global emissions (assuming 20 percent of its domestic emissions are generated by households), but the corporate entities located within it are ultimately responsible for producing seventeen times more greenhouse gas pollution than Australia's population arguably warrants.

Another fact which the energy and resource industries are reluctant to publicly admit is that they are 86 percent foreign-owned, meaning that the vast majority of the mining industry's annual profits go offshore [79]. Even less well known is the fact that the 'Big Four' accountancy firms, i.e. KPMG, PwC, Deloitte and Ernst \& Young have enabled the fossil fuel industry to avoid paying tens of billions of dollars in income taxes and royalties for publicly-owned fossil fuel resources over many years [80-84]. The Big Four are responsible for auditing 98 percent of

Table 2

Australian government public finance for fossil fuel industry projects, 2013 \& 2014. Source: Makhijani \& Doukas (2014).

\begin{tabular}{ll}
\hline PUBLIC FINANCE ENTITY & $\mathbf{2 0 1 3} \& \mathbf{2 0 1 4}$ \\
\hline Export Finance \& Insurance Corporation (domestic \& international) & $\$ 317$ million \\
Mutlilateral Development Banks & $\$ 209$ million \\
GRAND TOTAL & $\$ 526$ million
\end{tabular}




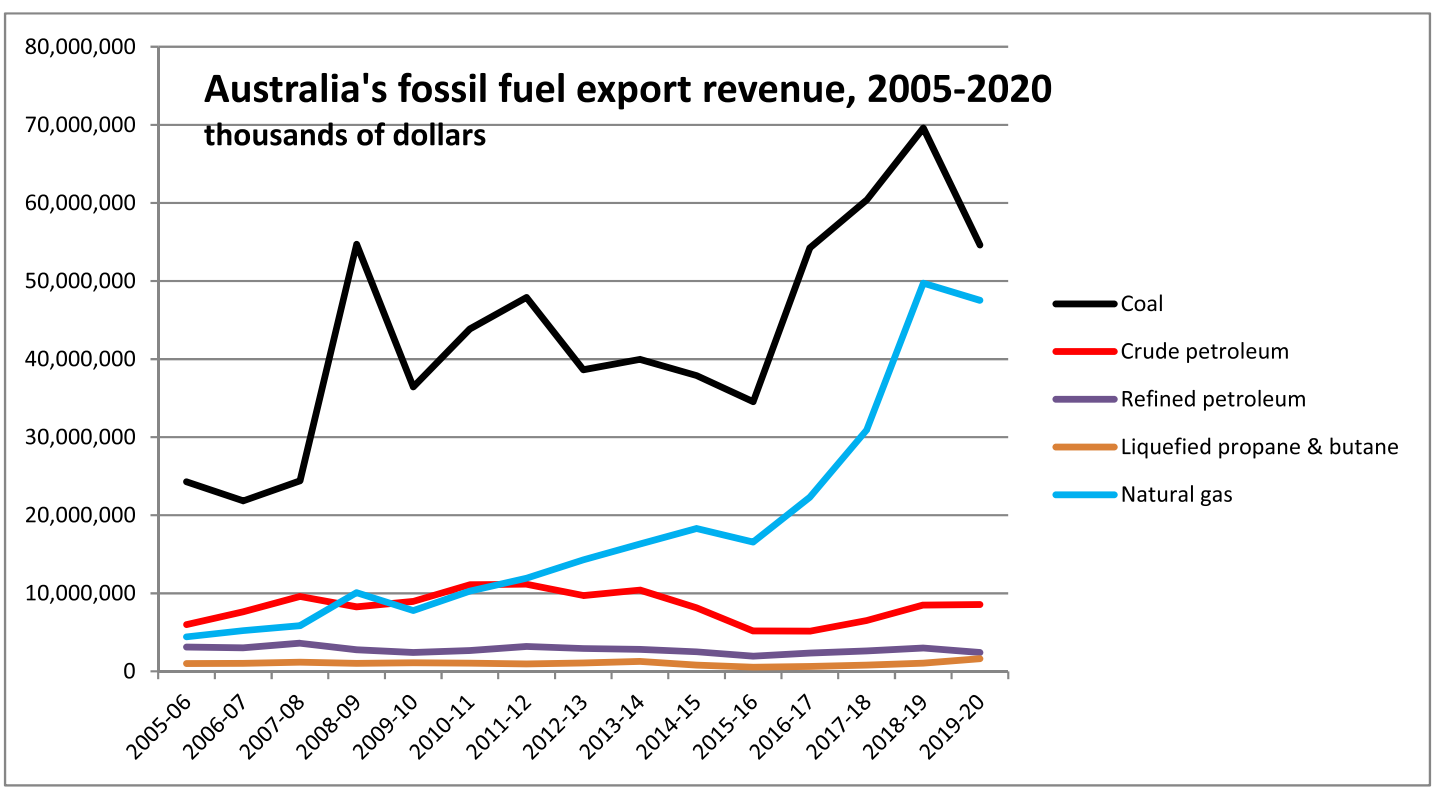

Fig. 2. Australia's fossil fuel export revenue by major category, 2005-2020. Source: DFAT (2021).

global corporations with a turnover of US $\$ 1$ billion or more, and reputedly cost governments and taxpayers around the world more than US\$1 trillion in annual revenue [85]. Between 2012 and 2018, thirteen of the Big Four's largest Australian clients in the coal, oil and gas industries generated well in excess of $\$ 160$ billion in Australian revenues, but paid less than $\$ 12$ million in income tax on that revenue, or 0.007 percent of total revenue. ${ }^{3}$ By way of contrast, their ten most 'responsible' resource and energy clients generated $\$ 415.4$ billion in total revenue between 2015 and 2018, and paid $\$ 21.1$ billion in income tax, or 5 percent of their total revenue (Tables 3 and 4). The contents of these tables and their implications will be examined in more detail in Section 5 .

The Big Four are notorious for treating conflicts of interest as revenue streams. They were paid more than $\$ 3.1$ billion in consultancy fees by the Federal Coalition Government between 2012 and 2018 [86], in lieu of the public service expertise which the Coalition has purged from the

Table 3

Top resource \& energy tax avoiders 2015-2018. Source: Michael West Media (2020).

\begin{tabular}{llll}
\hline & COMPANY & TOTAL REVENUE & INCOME TAX PAID \\
\hline 1 & ExxonMobil & $\$ 33.1$ billion & $\$ 0$ \\
2 & Energy Australia & $\$ 30.2$ billion & $\$ 0$ \\
3 & Santos & $\$ 14.9$ billion & $\$ 3.1$ million \\
4 & Peabody Australia & $\$ 12.2$ billion & $\$ 0$ \\
5 & Chevron Australia & $\$ 10.5$ billion & $\$ 0$ \\
6 & BG International & $\$ 9.7$ billion & $\$ 0$ \\
7 & BNP Paribas SA & $\$ 9.6$ billion & $\$ 0$ \\
8 & Puma Energy & $\$ 9.4$ billion & $\$ 0$ \\
9 & Citic Resources Australia & $\$ 8.4$ billion & $\$ 0$ \\
10 & Sime Darby Industrial Australia & $\$ 7.5$ billion & $\$ 8.6$ million \\
11 & Yancoal Australia & $\$ 6.8$ billion & $\$ 0$ \\
12 & UGL & $\$ 6.4$ billion & $\$ 0$ \\
13 & Victoria Power Networks & $\$ 6.1$ billion & $\$ 0$ \\
& TOTALS & $\$ 164.8$ billion & $\$ 11.7$ million \\
\hline
\end{tabular}

\footnotetext{
${ }^{3}$ Unless otherwise stated, all dollar figures provided are in Australian dollars. On 4 April 2021, AUD1.00 = USD0.76.
}

Table 4

Top resource \& energy tax payers 2015-2018. Source: Michael West Media (2020).

\begin{tabular}{llll}
\hline & COMPANY & TOTAL REVENUE & INCOME TAX PAID \\
\hline 1 & BHP Billiton & $\$ 100.2$ billion & $\$ 7$ billion \\
2 & Rio Tinto & $\$ 92.6$ billion & $\$ 6.8$ billion \\
3 & Woodside Petroleum & $\$ 21.8$ billion & $\$ 1.2$ billion \\
4 & Shell Energy Holdings & $\$ 47.5$ billion & $\$ 1.1$ billion \\
5 & Robe River Mining & $\$ 6.4$ billion & $\$ 1.1$ billion \\
6 & Hancock Prospecting & $\$ 7.1$ billion & $\$ 1$ billion \\
7 & BP Regional Australia & $\$ 78.3$ billion & $\$ 0.9$ billion \\
8 & Mitsui Australia & $\$ 16.9$ billion & $\$ 0.9$ billion \\
9 & Alco Australia & $\$ 11.9$ billion & $\$ 0.6$ billion \\
10 & AGL Energy & $\$ 32.7$ billion & $\$ 0.5$ billion \\
& TOTALS & $\$ 415.4$ billion & $\$ 21.1$ billion \\
\hline
\end{tabular}

federal bureaucracy over many years as the result of successive waves of austerity and 'rationalization'. It should be noted that this is, however, only a small fraction of the $\$ 129$ billion spent by the Coalition on outsourcing consultancy and non-consultancy services to the private sector over the five-year period from 2012 to 2017, which has gutted public sector service provision [87]. Although they routinely advise both corporations and governments regarding tax arrangements, the Big Four have been afforded permanent secondment positions in Australian government departments. Having effectively infiltrated government on behalf of their corporate clients, they have managed to successfully fend off all efforts to remove the 'grandfathering' of tax concessions for the oil and gas industry over many decades. Nevertheless, the many conflicts of interest in which the Big Four are involved have never been officially investigated or acknowledged [80,86,88-92]. They are, therefore, important enablers of the fossil fuel industry's political and economic power, and provide a fifth indicator of corporate state capture.

A sixth indicator of state capture is the success of Australian negotiators in winning major concessions for Australia under the Kyoto Protocol. After several years of intense lobbying, Australia was permitted to increase national emissions by 8 percent relative to 1990 levels, and to use carbon sinks to offset its transport and energy emissions. It is well documented that Australian government representatives have acted in concert with other fossil fuel producing and exporting nations as industry advocates, and have played a spoiler role in international diplomacy surrounding action on climate change [93]. During 
the premiership of Liberal leader John Howard, Australia's negotiating team was dominated by fossil fuel and mining interests. A number of fossil fuel and mining executives also claimed they had drafted Australian climate and energy policies during Howard's term in office $[10,11]$. Australia was only able to meet its Kyoto Protocol target between 2008 and 2012 by offsetting its higher emissions from electricity, transport and industrial processes with reductions in its emissions from land clearing, forestry and waste disposal [12: 24, [57]: 62]. Subsequent to signing the Paris Agreement in 2015, the Federal Coalition Government is yet to endorse any policies that will achieve the emission reductions to which it has committed $[7,94,95]$.

It is nevertheless important to point out that the ALP is far from blameless with respect to ensuring the continued incumbency of the fossil fuel industry in providing for Australia's transport and energy needs. Although several Labor state and territory governments have implemented policies to increase the proportion of renewable electricity generation within their own jurisdictions [96], and several Federal Labor senators have supported the phase out of coal-fired power stations [97, cf. 98,99], the ALP continues to oppose any suggestion that thermal coal mining should be phased out [100,101, cf. 57], and continues to support further expansion of the industry [102]. It has also remained silent on the issue of breaking up the vertically-integrated oligopolies that successive governments have enabled and which continue pricegouging retail customers in electricity generation and transmission [103-110]. It has likewise had nothing to say regarding the cartel that has emerged in gas production and supply which it helped to establish over the last decade [111-114]. Although it has recently announced a revamped electric vehicle policy [115], it does not appear to have any policies on improving vehicle emission standards, despite transport sector emissions continuing to grow since the early 1990s [116]. It has also shown no willingness to address the regulatory capture of some of the agencies charged with public oversight of the energy and resource sectors [106,117-120, cf. 121 on similar problems in the UK], and has made no concrete commitment to decarbonise the whole economy, or to provide for a just transition for fossil fuel workers [35,122-124]. Because the Coalition has been similarly reluctant to act on any of these issues, which constitute at least seven other policy areas in which the fossil fuel industry has been successful in achieving its goals, the number of indicators of corporate state capture rises to thirteen.

Apart from these thirteen policy areas, it has been widely reported that the fossil fuel and resource extraction industries have managed to successfully repeal a national price on carbon, prevented the introduction of policies promoting electric vehicles, demonized efforts to phase out coal exports, and overcome state-wide moratoria on coal seam gas extraction. They have also been instrumental in weakening environmental regulations, strengthening anti-protest laws, and ensuring the removal of two insufficiently compliant prime ministers, i.e. Kevin Rudd (ALP) and Malcolm Turnbull (Coalition) [125-129]. Despite having ample warning that it needed to act, the Federal Government allowed Shell and Caltex/Mobil to close most of their remaining oil refineries in Australia, with the result that the country now has a dangerously inadequate strategic petroleum reserve which is reliant on US reserves for support $[130,131]$. Both state and federal governments have failed to legislate for any kind of domestic gas reserve, and allowed virtually all of the country's massively increased gas production to be exported, leading to similarly massive price rises in the cost of domestic gas for all consumers $[132,112,133]$. The industry has also been granted legal exemptions on environmental controls, including for its profligate use and pollution of scarce water resources, and burning gas flares during intense fire conditions $[134,135]$. These constitute another eleven indicators of corporate state capture, bringing the total to twenty-four (Table 5).
Table 5

Indicators of state capture by the fossil fuel industry in Australia.

\begin{tabular}{|c|c|c|}
\hline Indicator & Jurisdiction & $\begin{array}{l}\text { Bipartisan } \\
(\mathrm{Y} / \mathrm{N})\end{array}$ \\
\hline $\begin{array}{l}\text { Increases of } 34-63 \text { percent in emissions from } \\
\text { energy, transport \& industry from } 1990 \text { to } \\
2020 \text {. }\end{array}$ & State \& Federal & $\mathrm{Y}$ \\
\hline $\begin{array}{l}\text { Maintenance \& expansion of fossil fuel } \\
\text { subsidies \& financing for infrastructure } \\
\text { from government. }\end{array}$ & $\begin{array}{l}\text { Federal, NSW, } \\
\text { Qld, WA }\end{array}$ & $\mathrm{Y}$ \\
\hline $\begin{array}{l}\text { No regulation of carbon risk in the } \\
\text { superannuation industry. }\end{array}$ & Federal & $\mathrm{Y}$ \\
\hline $\begin{array}{l}\text { Tripling of coal production and quintupling } \\
\text { of gas production since } 1990 \text {. }\end{array}$ & $\begin{array}{l}\text { Federal, NSW, } \\
\text { Qld, WA, NT }\end{array}$ & $\mathrm{Y}$ \\
\hline $\begin{array}{l}\text { No action on conflicts of interest for Big Four } \\
\text { accountancy firms and their enabling of } \\
\text { tax avoidance by major fossil fuel firms. }\end{array}$ & Federal & $\mathrm{Y}$ \\
\hline $\begin{array}{l}\text { Major concessions won under Kyoto } \\
\text { Protocol to increase emissions by } 8 \% \text { on } \\
1990 \text { levels and include carbon sinks for } \\
\text { emission mitigation. }\end{array}$ & Federal & $\mathrm{Y}$ \\
\hline $\begin{array}{l}\text { No policies on phasing out thermal coal or } \\
\text { gas production. }\end{array}$ & State \& Federal & $\mathrm{Y}$ \\
\hline $\begin{array}{l}\text { No effort to break up vertically-integrated } \\
\text { oligopolies in electricity generation and } \\
\text { retailing. }\end{array}$ & State \& Federal & $\mathrm{Y}$ \\
\hline $\begin{array}{l}\text { No effort to break up the cartel in Australian } \\
\text { gas production. }\end{array}$ & Federal & $\mathrm{Y}$ \\
\hline $\begin{array}{l}\text { No policy on improving vehicle fuel } \\
\text { efficiency standards. }\end{array}$ & Federal & $\mathrm{Y}^{10}$ \\
\hline $\begin{array}{l}\text { No effort to address regulatory capture of } \\
\text { key government agencies in the energy \& } \\
\text { resource sectors. }\end{array}$ & State \& Federal & $\mathrm{Y}$ \\
\hline $\begin{array}{l}\text { No commitment or plan to decarbonise the } \\
\text { whole economy. }\end{array}$ & State \& Federal & $\mathrm{Y}$ \\
\hline No plan for a just transition for coal workers. & State \& Federal & $\mathrm{Y}^{11}$ \\
\hline $\begin{array}{l}\text { Repeal of a national price on carbon by the } \\
\text { Coalition. }\end{array}$ & Federal & $\mathrm{N}$ \\
\hline $\begin{array}{l}\text { No coherent national or state-based policies } \\
\text { on electric vehicles. }\end{array}$ & State \& Federal & $\mathrm{Y}^{12}$ \\
\hline No policy on reducing coal exports. & State \& Federal & $\mathrm{Y}$ \\
\hline $\begin{array}{l}\text { Abolition of state-wide moratoria on coal } \\
\text { seam gas extraction. }\end{array}$ & NSW, WA, NT & $\mathrm{Y}$ \\
\hline $\begin{array}{l}\text { Weakening of environmental regulations for } \\
\text { fossil fuel projects. }\end{array}$ & $\begin{array}{l}\text { Federal, NSW, } \\
\text { WA, Qld, NT }\end{array}$ & $\mathrm{Y}$ \\
\hline $\begin{array}{l}\text { Strengthening of anti-protest laws to curb } \\
\text { environmental activism. }\end{array}$ & Federal, NSW, Qld & $\mathrm{Y}$ \\
\hline $\begin{array}{l}\text { Removal from office of two insufficiently } \\
\text { fossil-friendly prime ministers. }\end{array}$ & Federal & $\mathrm{Y}$ \\
\hline $\begin{array}{l}\text { Enabled closure of strategic oil refineries by } \\
\text { oil majors. }\end{array}$ & Federal & $\mathrm{Y}$ \\
\hline $\begin{array}{l}\text { A dangerously inadequate strategic } \\
\text { petroleum reserve. }\end{array}$ & Federal & $\mathrm{Y}$ \\
\hline No domestic gas reserve. & $\begin{array}{l}\text { Federal, NSW, } \\
\text { WA, Qld, NT }\end{array}$ & $\mathrm{Y}$ \\
\hline $\begin{array}{l}\text { Exemption of fossil fuel projects from } \\
\text { environmental regulations. }\end{array}$ & $\begin{array}{l}\text { Federal, WA, } \\
\text { NSW, Qld, NT }\end{array}$ & $\mathrm{Y}$ \\
\hline
\end{tabular}

${ }^{10}$ It should be noted, however, that the most recent Federal Budget measure providing $\$ 2$ billion in support for the country's two remaining oil refineries includes $\$ 300$ million for infrastructure upgrades to improve fuel quality to 'world's best practice' by 2024 . There remains no policy to improve vehicle fuel efficiency standards.

11 The ALP claims to have a policy on a just transition for coal workers but it is impossible to locate and is never publicly discussed.

12 Several Coalition and ALP-governed states have recently introduced EVrelated legislation, but it is neither coherent nor national in remit.

Important elements of how the industry achieved these goals are neither public nor scrutable. While deep divisions over climate and energy policy undoubtedly exist within and between factions in Australia's major political parties, those divisions do not explain their 
seeming inability to acknowledge or recognize the need for significant institutional reform of the electricity and transport sectors, or reforms to the ways in which taxes and royalties are collected from major coal, gas and oil projects. The major parties have repeatedly failed to act when clear instances of malfeasance and illegal behaviour by energy and mining companies have been exposed, including widespread tax avoidance [81-83,88,136-139]. Such behaviour is not convincingly explained by shared ideological preferences or development narratives. Similarly, although some fossil energy and resource firms have publicly endorsed action on climate change, or removed themselves from peak industry bodies that were openly engaged in climate change denial, behind the scenes many of those same companies have continued funding efforts to undermine decarbonisation, including ExxonMobil, Royal Dutch Shell, Chevron, BP, Total and Woodside, all of which have major stakes in oil and gas projects in Australia [140-142]. All of these companies have also been engaged in aggressive tax avoidance (Tables 3 and 4 ; 143). As we will see in Section 4 of this paper, they have also made large donations to the major political parties, employ an army of lobbyists to court them, and regularly employ senior public officials from key government portfolios, while simultaneously implanting their own operatives in those portfolios.

\section{Theorizing the social power of covert networks in Australia's energy and resource sectors}

\section{The definition of the alternatives is the supreme instrument of power.} E.E. Schattschneider (1960): 68.

In a landmark empirical study that examined the voting patterns of incumbent politicians in the United States, Martin Gilens and Benjamin Page demonstrated that the policy and voting preferences of US politicians correlate strongly with those of business and industrial elites, and very weakly or not at all with those of the general public, except in cases where the preferences of elites and publics align [144]. Drawing on a large and diverse set of almost 1779 policy cases between 1981 and 2002 their findings strongly support political theories of economic-elite domination and biased pluralism, as opposed to theories of majoritarian electoral democracy and majoritarian pluralism. According to biased pluralism theories, the interests of corporations, business associations and professional groups tend to predominate over those of the 'average citizen' and mass-based interest groups, particularly when the scope of conflict is narrow and public visibility is low [39-43,145]. According to elite domination theories, individuals with high social status occupying key institutional positions in government, business, industry and the military have common interests, backgrounds and social networks [42]. Those individuals who form economic elites by dint of their high incomes and wealth work through foundations, think-tanks and other 'opinion-shaping apparatus', together with the politicians and lobbyists they finance, to dominate government decision-making, despite the existence of democratic electoral processes [43]. Both theoretical approaches indicate that a combination of structural biases in the institutions of government and various forms of 'soft corruption' provide more convincing explanations of why such preferences find such consistent political expression than theories which rely solely on the productive power of ideologies [146-148] or discourses [35,36].

There are a number of ongoing research projects in the US, UK, Australia and Canada documenting the 'revolving door' phenomenon in a number of different sectors [e.g. [65,140,149-152]. A number of recent studies have focused upon networks of corporate influence in the fossil fuel and resource extraction industries, building and construction, finance and banking, transport and logistics, gaming and racing, health and aged care, pharmaceuticals, defense and telecommunications [153-159]. However, with the exceptions of recent global studies by Australian-based researchers [160-162] and the pioneering investigations of Clive Hamilton, Guy Pearse, and several other scholars with a journalistic background [9-12,163-168], questions of market power and corporate influence in relation to climate change and energy policy in Australia do not generally inform the academic literature and therefore remain under-theorized.

The 'capital as power' (CaP) theoretical framework developed by Jonathan Nitzan and Shimshon Bichler provides an overarching framework for conceptualizing the political economy of contemporary capitalist societies and their dependence on fossil energy which can accommodate theories of economic-elite domination and biased pluralism [44]. CaP is also able to explain why the governments of nation states habitually favour the interests of global corporations in their efforts to make and control markets $[2,169]$. Drawing on the institutionalist tradition in political economy founded by Thorstein Veblen, CaP argues that since the emergence of industrial capitalism, financialization has become the standard method used by powerful corporations to achieve and maintain political and economic dominance across multiple sectors and jurisdictions. In order for these corporations to maintain their dominance, it is essential that the political elites of the nation states in which those corporations are headquartered, or from which they derive significant revenues, maintain the perception that those corporations' activities are legitimate, and that their future profitability is assured $[1,161]$. Those who comply are rewarded with generous political donations and lucrative post-parliamentary careers. Those who do not are opposed, rendered ineffective through whatever means are necessary, and ultimately removed from office. It follows from this that expert advice to decision-makers in both the public and private sectors, no matter from where it originates, will always be subservient to dominant financial interests should that advice not prove consistent with maintaining favourable perceptions of their future ability to earn more than the average rate of investment return.

According to Nitzan and Bichler, the power of capital lies not in its ability to produce, but in its ability to incapacitate, i.e. the power to sabotage [44: 231]. In their view, 'capital income depends not on the growth of industry, but on the strategic control of industry' [44: 322]. Monetary accumulation is both the goal and the means of gaining financial success, while capitalization is the tool for assigning values to fortunes, which are in turn based on expected earnings discounted against the probability that those earnings will not be realized [44: 262]. They argue that dominant capital seeks to 'shape and restructure the course of social reproduction at large' within a broader framework of social struggle between capitalist elites, and between capitalists and labour. This power struggle is characterized by attempts to accumulate the ability to subjugate creativity to power [44: 218]. Thus, the concentration of social power in the hands of ruling elites is a function of their ability to craft policy and regulatory regimes, appropriate the creativity of others, sabotage the efforts of competitors and rivals, and concentrate wealth and income in their own hands. It follows from this that the most powerful elites in our societies are those whose incomegenerating assets are the most highly financialized, which includes the publicly-listed, privately-owned and state-run fossil fuel companies.

Political economist John Mikler points out that only 10 percent of the world's public companies are responsible for generating 80 percent of global profits. The largest of those companies, i.e. those with more than US $\$ 1$ billion in annual revenue, generate 60 percent of global revenues 
and 65 percent of global market capitalization. Because it is not at all unusual for only four global corporations to control 40 percent or more of total revenue in major industrial sectors, those corporations are able to punish or reward nation states and regional governments for the provision of favourable investment conditions [162: 40-41]. In Australia, such oligopolies exist in the oil, coal and gas industries, electricity generation, aviation, banking and finance, transport and logistics, mining and resources, and metals processing, i.e. all of those industries responsible for greenhouse gas pollution and the financing of those industries' activities. For Nitzan and Bichler, their level of market capitalization determines the extent to which they are able to shape national and international legislative and regulatory regimes. High levels of market capitalization enable corporations to make and control global markets through their exercise of structural, instrumental and discursive forms of power [162: 40-45]. The following discussion focuses on the structural and instrumental forms of power exercised by the fossil fuel and resource extraction industries, which are then explicated through the empirical analysis in Section 5.

Following Nitzan and Bichler's reasoning, the ability of dominant corporations to shape government policy is directly correlated to the level of their financial investments in that country, and whether those investments are in critical economic sectors, both of which give them structural power to shape market conditions in their favour. Structural power encompasses all those activities which enable political actors to set agendas by "creating or reinforcing social and political values and institutional practices that limit the scope of the political process to public consideration of only those issues which are comparatively innocuous' to them [170]. The quote above from Schattschneider refers to a key feature of structural power: the power to define the alternatives. In the context of this discussion, it implies that the more significant the financial interest of a corporation or industry peak body in a critical sector, the greater its preparedness and ability to exercise its political and economic power over governments and civil society. This can include offers of investment and threats of disinvestment in a country, region or city, or determining what are acceptable and unacceptable forms of economic interaction. When the financial interests of corporations coalesce, collective action enables them to realize their goals more easily. Cooperation and coordination are more likely to occur when they are faced with a common threat. In those cases where there is oligopolistic domination of a sector by several large firms, cooperation enables them to pool their resources and thereby reduce the costs of neutralizing that threat. All of these things are, of course, true of the fossil fuel, electricity and resource extraction industries.

The ability of dominant corporations' to shape relevant policy and regulatory regimes in their favour also occurs through various forms of instrumental power. These constitute forms of direct influence whereby one actor exercises leverage over another actor in order to achieve an instrumentally motivated outcome that the second actor would not otherwise pursue [171]. Traditional realist accounts of international relations assume we live in an anarchic world in which instrumental power is exercised through various forms of coercion by one nation state over another that in turn creates imbalances of power that produce conflict or stability [162: 35]. It is very clear that corporations now play a significant role in inter- and intranational relations, exercising their instrumental power over one another and the nation states in which they operate through public relations campaigns, lobbying, political donations and revolving door appointments. Business in general and corporations in particular have greatly expanded their activities in all four areas since the early 1970s [172]. Such practices are now common in most countries, particularly in those parts of the economy where significant amounts of revenue are routinely generated and expended. Corporations involved in economic activities that are highly regulated tend to invest more resources pursuing these strategies, which is true of the fossil fuel, electricity and resource extraction industries [173].

Lobbying is one of the oldest forms of instrumental power exercised by the wealthy and influential. In recent decades it has become a multi- billion dollar business, with hundreds of thousands of lobbyists working in thousands of firms throughout the world regularly exerting pressure on governments to do their bidding. There is ample evidence to indicate that these efforts are extremely effective. One US study published in 2009 found a 22,000 percent return on investment for every $\$ 1$ spent on tax lobbying, and that the larger the industry and firm size, the greater the return [174]. Political donations buy access to parliamentarians and to favourable political outcomes. They also establish personal relationships between the donor and the donee, which are often cultivated over many years and facilitate revolving door appointments between the donating firm and governing bodies, as well as post-political career pathways for compliant politicians, political staffers and senior bureaucrats. Major corporations expend considerable time and resources courting individuals who hold public office in relevant portfolios as potential allies and future employees, sometimes as lobbyists, sometimes as advisors, sometimes as consultants, and other times as board members and company directors. By implanting their own current and former staff members in the positions of political staffers and the senior echelons of relevant bureaucracies, they are even more powerfully enabled to achieve their goals. It is important to note that to the extent that any of these strategies remain undocumented, they constitute covert forms of influence. The resulting social networks are thus far more powerful than any advocacy coalition, and less amenable to any form of public scrutiny than a discourse coalition. It is therefore relatively straightforward in most circumstances for opponents of governance reform to discredit claims of covert corporate influence if there is no 'smoking gun' directly linking corporate interests to certain government decisions.

In the context of policy and regulation, the use of both structural and instrumental forms of power through sabotage can best be practiced covertly through undisclosed political donations, undocumented lobbying practices, and concealed business relationships involving conflicts of interest. Two useful terms for characterizing the kinds of covert forms of political activity that characterize strategies of sabotage were coined by the Canadian diplomat and academic Peter Dale Scott. In his examination of the covert networks linking the illicit narcotics trade, the petroleum industry, and the US war machine, he coined the term 'deep politics' to refer to 'all those political practices and arrangements, deliberate or not, which are usually repressed rather than acknowledged', and 'para-politics' to denote conduct carried out through 'indirection, collusion and deceit' $(45,46$, cf. 26,47$)$. Although Scott developed these terms to describe covert links between mainstream politicians, fossil fuel and finance companies, military and intelligence agencies, and organized crime in the United States, these terms are equally applicable to the anti-democratic networks of covert influence currently operating between industry, politics and the media in Australia. Indeed, many of the Australian networks documented in Section 4 of this paper include US-headquartered fossil fuel corporations previously implicated by Scott and other credible sources in illicit activities which have so far escaped prosecution.

The kinds of para-political activities that occur in Australia take place through social connections between individuals working in and for departments, agencies and other quasi-autonomous bodies within corporations, governments, political parties, peak organizations, and public relations and consultancy firms. Economists Cameron Murray and Paul Frijters have described these insider networks as a 'game of mates', wherein rent-seeking by business and industry is focused on gaining privileged access to decision-makers, resulting in billions of dollars being siphoned off annually from government coffers to line the pockets of 'mates' in the mining, finance, transport, property and other industries [158]. The 'game of mates' is played so well in Australia that 63 percent of its billionaires have attained their wealth through political connections, in much the same manner as India and Colombia, as opposed to 1 percent in the United States [175]. More than 80 percent of Australia's richest 200 Australians have made their fortunes in property, mining, banking, superannuation and finance, all of which are heavily 
Table 6

Reports published by multiple sources on revolving door, lobbying and political donations relating to Australia's fossil energy sector, Jan 2007 - Mar 2021.

\begin{tabular}{|c|c|c|}
\hline Information Source & $\begin{array}{l}\text { Reports of revolving door, } \\
\text { lobbying \& political } \\
\text { donations related to fossil } \\
\text { energy (excl. ICAC NSW) }\end{array}$ & $\begin{array}{l}\text { Reports on ICAC inquiries } \\
\text { into NSW politicians } \\
\text { involved in fossil fuel } \\
\text { corruption }\end{array}$ \\
\hline \multicolumn{3}{|l|}{ Government Agencies } \\
\hline $\begin{array}{l}\text { Independent } \\
\text { Commission } \\
\text { Against Corruption }\end{array}$ & - & 7 \\
\hline \multicolumn{3}{|c|}{ Government-funded Media } \\
\hline $\begin{array}{l}\text { Australian } \\
\text { Broadcasting } \\
\text { Corporation }\end{array}$ & 21 & 320 \\
\hline \multicolumn{3}{|l|}{ Daily Newspapers } \\
\hline The Advertiser & 2 & 259 \\
\hline The Australian & 8 & 120 \\
\hline $\begin{array}{l}\text { The Australian } \\
\text { Financial Review }\end{array}$ & 3 & 196 \\
\hline The Daily Telegraph & 2 & 259 \\
\hline The Courier Mail & 1 & 259 \\
\hline $\begin{array}{c}\text { The Guardian } \\
\text { Australia }\end{array}$ & 28 & 288 \\
\hline Newcastle Herald & 3 & 187 \\
\hline news.com.au & - & 107 \\
\hline 9news.com.au & 3 & 125 \\
\hline $\begin{array}{l}\text { The Sydney Morning } \\
\text { Herald }\end{array}$ & 28 & 61 \\
\hline Sub-Total & 99 & 1670 \\
\hline \multicolumn{3}{|l|}{ Independent Media } \\
\hline Australian Mining & 7 & 41 \\
\hline Crikey! & 11 & 83 \\
\hline Green Left Weekly & 16 & 32 \\
\hline Independent Australia & 35 & 58 \\
\hline Michael West Media & 46 & 10 \\
\hline New Matilda & 7 & 16 \\
\hline RenewEconomy & 7 & - \\
\hline The Saturday Paper & 13 & 23 \\
\hline Sub-Total & 142 & 263 \\
\hline \multicolumn{3}{|l|}{ NGOS } \\
\hline The Australia Institute & 8 & - \\
\hline GetUp! & 1 & - \\
\hline $\begin{array}{l}\text { Transparency } \\
\text { International }\end{array}$ & 1 & - \\
\hline TOTAL & 251 & 1932 \\
\hline
\end{tabular}

regulated sectors in which enormous fortunes can be made through favourable planning, legal and regulatory exemptions, concessions and subsidies [176].

With respect to the fossil fuel and resource industries in Australia, former Liberal Party staffer Guy Pearse was the first to systematically document such activities in his doctoral thesis [177], and his book and later essay based on that thesis $[11,12]$. Pearse's research revealed the extent to which polluting industries operating in Australia engaged in deep politics to capture the ruling Liberal and National parties at the federal level under Prime Minister John Howard. Pearse also intimated on several occasions that these covert relationships go deeper and further back in time to encompass the activities of previous federal Labor governments. It is perhaps unsurprising, therefore, that neither the Coalition nor Labor has shown any appetite to further investigate any of Pearse's findings. Polluting industries have carefully constructed and cultivated personal relationships with senior officials in the major political parties and key bureaucracies over many decades. These are deep political relationships which are not dependent on the reliability and availability of particular individuals.

\section{Developing a methodology for investigating covert networks of political influence}

The methodology adopted in the next section of the paper involves using investigative and quantitative techniques combined with social network analysis. The research which informs it began with a search of more than 250 news reports discussing political donations, revolving door and lobbying activities in the Australian energy and resource sectors covering the period from 2007 to 2021 [Table 6]. These reports were located by conducting a series of systematic searches of twenty-two relevant websites, including one government anti-corruption agency, ten newspapers, ${ }^{4}$ one government-funded news service, seven independent media sites, and three NGOs. The initial searches included the compilation of almost 2000 reports relating to a series of corruption findings against several ALP and Coalition parliamentarians in NSW over coal and gas licenses in the late 2000s. The latter reports are itemized in the right hand column of Table 6. Although they clearly indicate the high level of attention to these issues by the mainstream media, it is the independent media that has more consistently focused on stories about revolving door appointments, lobbying and political donations related to the fossil fuel industry, as captured in the central column of Table 6 .

Of the 251 reports listed in the central column, around 60 contained information pertaining to current or former senior politicians, political staffers and bureaucrats who currently or formerly held key positions in the energy and resource portfolios and who had also previously or subsequently worked for a fossil energy, electricity or resource company or industry peak body. The relevant articles were revealed by doing more detailed searches combining one of the terms 'fossil fuels', 'electricity', 'coal', 'gas', 'petroleum' and 'mining' with one or more of the keywords 'lobby', 'revolving door', 'donations', 'campaign financing', 'gifts', 'incentive', 'bribery', 'corrupt', 'illegal' and 'public relations'.

The focus was upon stories that drew attention to the movements of these individuals from the public to private sector, or vice versa, and the kinds of responsibilities, policies and projects in which they had been involved. Most were written by staff writers who had a history of covering climate and energy policy issues [e.g. 178-187. Some of the stories related to state-based individuals, although most covered state and federal politics or federal politics exclusively.

Several attempts at systematizing these reports had previously been made by GetUp!, the Australian Greens, the Australian Conservation Foundation (ACF) and The Australia Institute (TAI) [e.g. 188,189. After making contact with these other organizations, databases were exchanged and a comparison and consolidation of the various sources into a single database was begun. The resulting database was then split into two sections:

a) Former Australian politicians with employment links to fossil fuel and resource extraction industries

b) Australian political staffers and senior bureaucrats with employment links to fossil fuel and resource extraction industries. ${ }^{5}$

Both databases contain details of the career movements and portfolio responsibilities of the individuals concerned, their party political affiliations (if any), and the periods during which they were employed in the various public and private positions which they occupied. The information contained in both databases was fact-checked and more detailed information entered about the documented individuals, including the months they had started or left employment. Employment histories were checked using several sources. Parliamentary websites and official Wikipedia pages were searched and cross-checked for details of politicians' terms in office and official positions. LinkedIn and corporate websites were searched for the employment histories of political staffers

\footnotetext{
${ }^{4}$ Five of these are owned by Rupert Murdoch's NewsCorp, including The Australian and news.com.au, with three simply reproducing the same stories across multiple mastheads, i.e. The Advertiser, The Courier Mail, and The Daily Telegraph, as can be seen in the right hand column of Table 6.

5 My use of the term 'fossil fuel industry' from henceforth includes companies and peak bodies involved in fossil-fuelled electricity generation.
} 
and senior bureaucrats who had worked in the private sector. State and federal lobbyist websites and registers in those Australian jurisdictions involved in fossil fuel extraction were also searched to gain some idea of how many consultancies and lobbyists were involved, and what kinds of issues they were primarily focused upon. ${ }^{6}$

A primary limitation of this methodology is the difficulty of locating publicly available information pertaining to the identities of political staffers working for politicians. It is therefore not always possible to determine who is working for whom. A second limitation is that some of the relevant politicians, staffers, lobbyists, bureaucrats and advisors are unwilling to publicly reveal the full extent of their employment activities and positions. Some of those being scrutinized via LinkedIn either improved or deleted their public profiles when it became apparent to them they were being monitored. A third limitation is that most of the lobbyist registers do not contain information about meeting dates, who was lobbied, or the topics discussed. Nevertheless, some additional information can be found through searches of official state and federal government websites, as well as corporate web pages and media releases from the many companies for whom the various individuals subsequently worked or consulted. Because there is a large amount of information about the employment histories of these individuals on the Internet, there were relatively few individuals whose details could not be revealed using these techniques.

In the next section, the two databases are used to create a number of charts and social network diagrams to graphically illustrate:

a) the positions occupied by, and relationships between, political staffers, senior bureaucrats and politicians, and the lobbying, consultancy, fossil energy and electricity firms and peak industry bodies for whom they previously or subsequently worked, including the jurisdictions in which they primarily operated, and

b) how those relationships correlate with known political donations and lobbying expenditure and tax avoided by the most prominent fossil energy firms and peak bodies documented.

More detailed research combining timelines of the employment histories of persons of interest and the introduction and approval of key enabling legislation in the interests of major corporate donors and patrons, as well as the blocking or amendment of such legislation, is currently underway and will appear in a subsequent research paper. It will also detail any major policy or infrastructure concessions occurring during the employment histories of key personnel.

\section{Connecting covert networks to lobbying, donations and the revolving door in energy policy}

The lack of regulation and transparency relating to political donations, lobbying and 'jobs for the boys' in Australia presents ample opportunities for structural biases which enable 'soft corruption' in government decision-making: a 'game of mates' for those with the right connections who make their own rules to the detriment of everyone else [158]. In this section, I draw upon the two databases described above containing the governance and employment histories of 160 former Australian politicians, bureaucrats and political staffers with clear employment links to the fossil fuel and resource extraction industries over the last fourteen years. More than 40 individuals in the database could not be definitively identified in this manner and so have been excluded from the analysis. The two databases include former Labor,

\footnotetext{
${ }^{6}$ For registers of lobbyists kept by the Australian, NSW, Qld, WA, Vic, SA and Tas governments, see: https://lobbyists.ag.gov.au/register; https://lobbyists.el ections.nsw.gov.au/; https://lobbyists.integrity.qld.gov.au/; https://lobbyists. wa.gov.au/; https://www.lobbyistsregister.vic.gov.au/lobbyistsregister/mai n/index.htm; https://www.dpc.sa.gov.au/responsibilities/lobbyist-registratio n; http://lobbyists.dpac.tas.gov.au/lobbyist_register
}

Liberal and National party ministers and their staffers, as well as senior bureaucrats, some of whom were or are directly employed as advisors, consultants and executives by fossil energy companies and peak bodies, while others are employed by lobbying firms and PR companies to promote the value of the industry to politicians across the political spectrum $[167,190]$. Guy Pearse has documented how polluting industry executives openly boasted about crafting and drafting climate change and energy policies under the Howard Coalition Government [11: 228-238, [12]: 31-45]. Because I have not attempted to secure confessions of this kind for the purposes of my own research, the analysis to follow focuses on the government secondment of industry operatives as political staffers and bureaucrats, and the employment by industry players of former senior bureaucrats, political staffers and ministers who demonstrated their loyalty and commitment while in public office. With regard to the career movements of senior politicians, I have previously described this phenomenon as a 'golden escalator' rather than a 'revolving door', because it rarely involves 'backwards and forwards' movements between the public and private sectors, in contrast to the many ministerial staffers who do so with dizzying regularity [190].

In order to demonstrate how fossil-fuelled interests continue to win a wide range of political favours from state and federal governments, and that corporate state capture of the country's incumbent political parties by the fossil fuel and resource extraction industries is a plausible explanatory hypothesis, the discussion to follow focuses on discernible financial and employment relationships between individuals and organizations, including political parties, bureaucracies, corporations and industry peak bodies via lobbying, political donations and 'jobs for the boys'. While these various activities are expressions of the instrumental power of the corporations concerned, they enable them to exercise structural power with respect to determining the shape of government policy and decision-making. Through these para-political relationships, which remain largely invisible to the public, they are able to sabotage any efforts to shift the political and economic agenda of Australia's major political parties. The extensive employment relationships between the individuals and entities concerned are documented in graphic representations of the data pertaining to political party affiliations, portfolio responsibilities and pre- and post-political employment. I then correlate these data with the levels of disclosed and undisclosed political donations and lobbying expenditure from the same companies employing former public officials, and the tax concessions which those companies and sectors have received.

Of the 38 current and former politicians with employment links to the fossil fuel industry, 20 are or were Liberal politicians, 13 were Labor politicians, and five are or were National politicians (Fig. 3). These figures demonstrate that Coalition politicians are twice as likely as ALP politicians to have pre- or post-political links to the fossil fuel industry. As we will see below, this is also generally reflected in the levels of political donations flowing to the ALP and Coalition from the fossil fuel and resource extraction industries. Furthermore, almost twice as many of the politicians identified served as federal members of parliament or senators, as opposed to those who built their careers in the states and territories, indicating that both industries see far more value in courting federal politicians (Fig. 4). The database contains no current or former politicians from Tasmania or the Northern Territory, reflecting Tasmania's low fossil resource base and the Federal Government's control of the rapidly expanding coal seam gas industry in the NT. It is worth briefly noting that there are 76 senators and 151 members of the House of Representatives in Australia's current federal parliament. Of the 24 federal politicians in the database, 16 were MPs and eight were or are senators, or about 10 percent of each group, all of whom occupied key portfolios related to energy and resources. A senator's single term is eight years, and an MP's term generally three or four years. There are no 


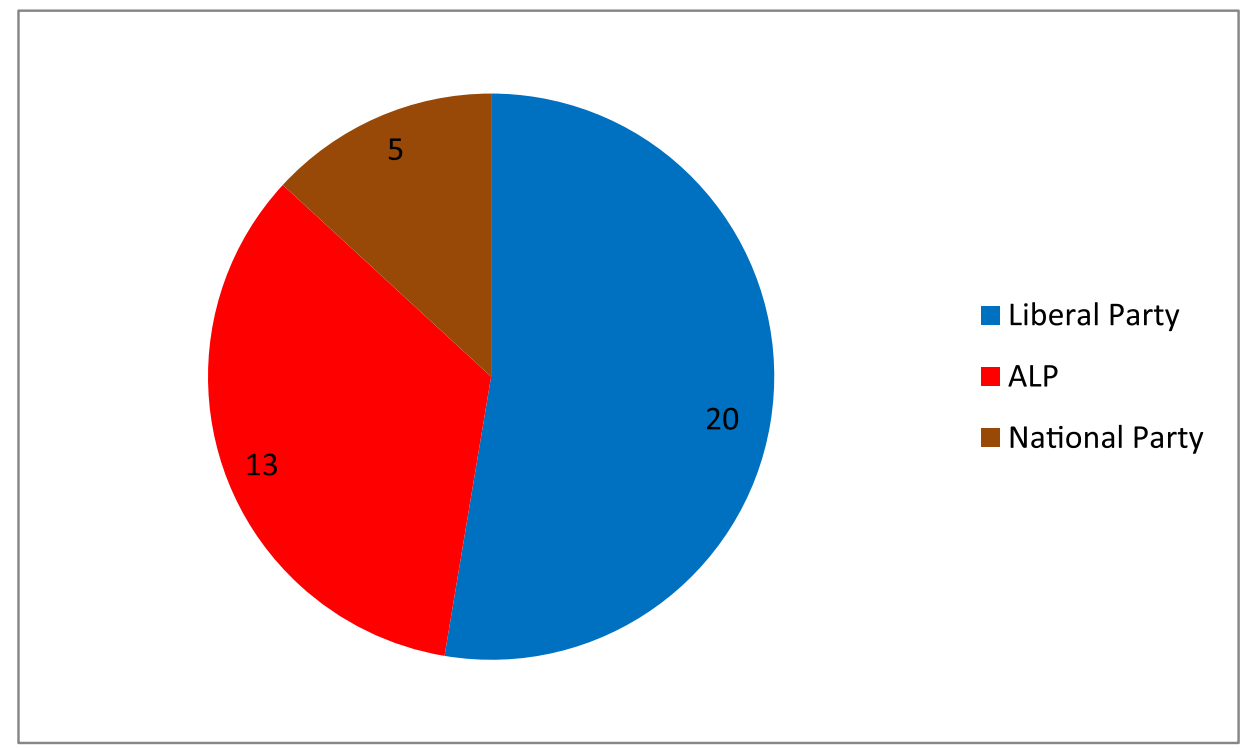

Fig. 3. Party political affiliations of 38 current and former ALP \& Coalition politicians with employment links to the fossil fuel industry.

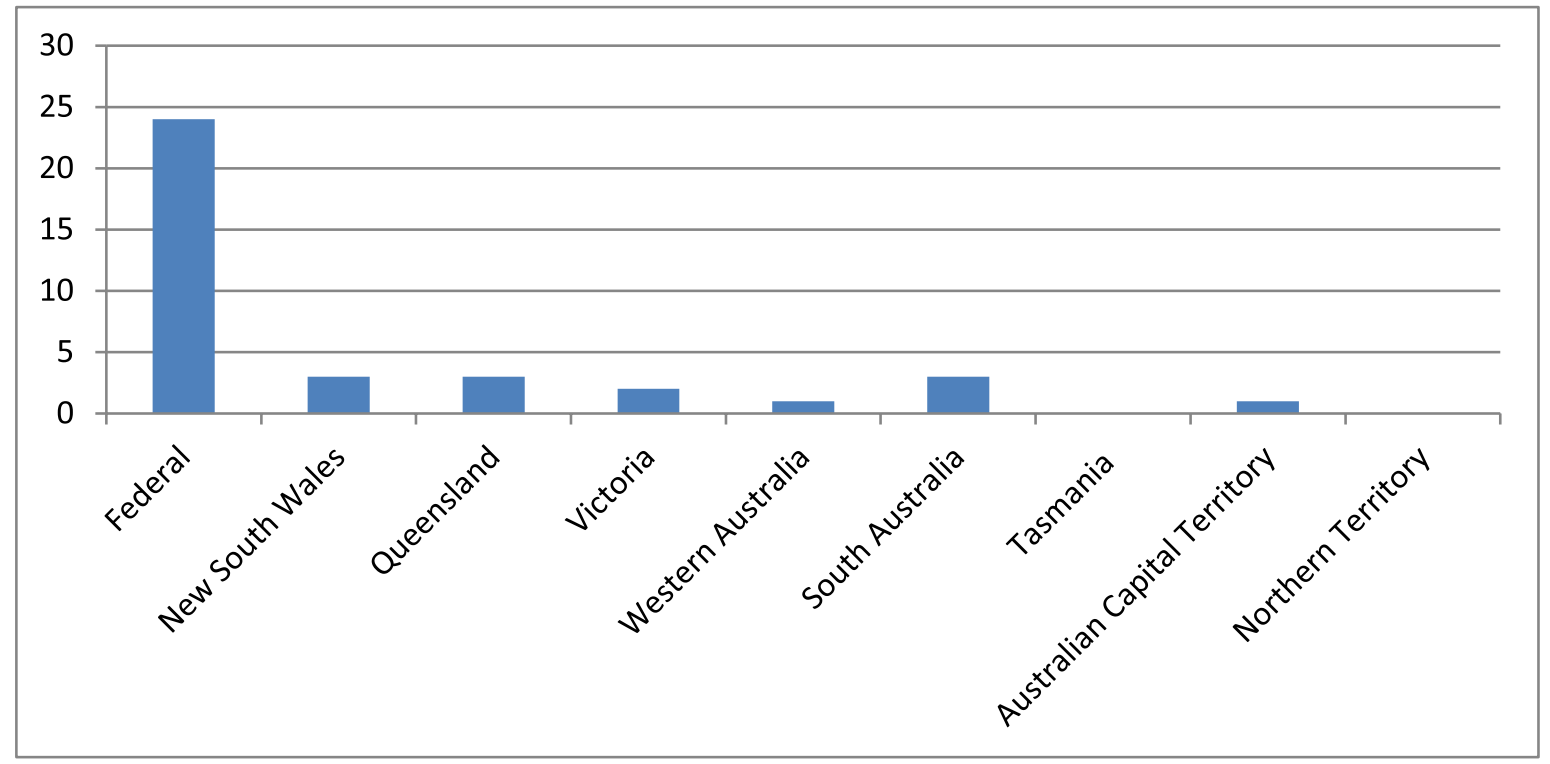

Fig. 4. State, territory and federal jurisdictions in which 38 politicians served with fossil fuel employment relations.

overall term limits in any Australian jurisdiction.

With regard to the ministerial positions occupied that had the most significant material bearing on the fortunes of the fossil fuel industry, only three of the 38 politicians in the database did not serve in ministerial positions. Three of the Liberal politicians served at both a federal and state level. The positions and/or portfolio areas in which the other 35 served are represented in Figs. 5 and 6. Because a number of the politicians concerned fulfilled multiple ministerial roles, the total number of positions exceeds the total number of politicians. Also, ministerial portfolios relevant to the analysis are often combined, so these are counted separately. It is clear from Fig. 5 that federal ministers for resources, energy, industry and trade were the most in demand, filling 23 of the 38 positions documented (60\%). Two leaders of the National
Party (who always fill the role of deputy prime minister when the Coalition is in power) and five treasurers and assistant treasurers bring the total representation of these highly influential portfolios to 74 percent of the total. It is likewise clear from Fig. 6 that, at the state and territory level, ministers of state and regional development, along with premiers, deputy premiers and ministers for energy, industry and trade, are the favoured portfolios, at 70 percent of the total. Given the key roles of the portfolios concerned, the seniority of the politicians who occupied the relevant ministerial positions, and the length of time they were in those positions, industry insiders undoubtedly perceived them as valuable assets to acquire for their knowledge and social connections.

With regard to the kinds of private sector positions that these politicians occupied in fossil-fuelled industries (all but one after retirement), 


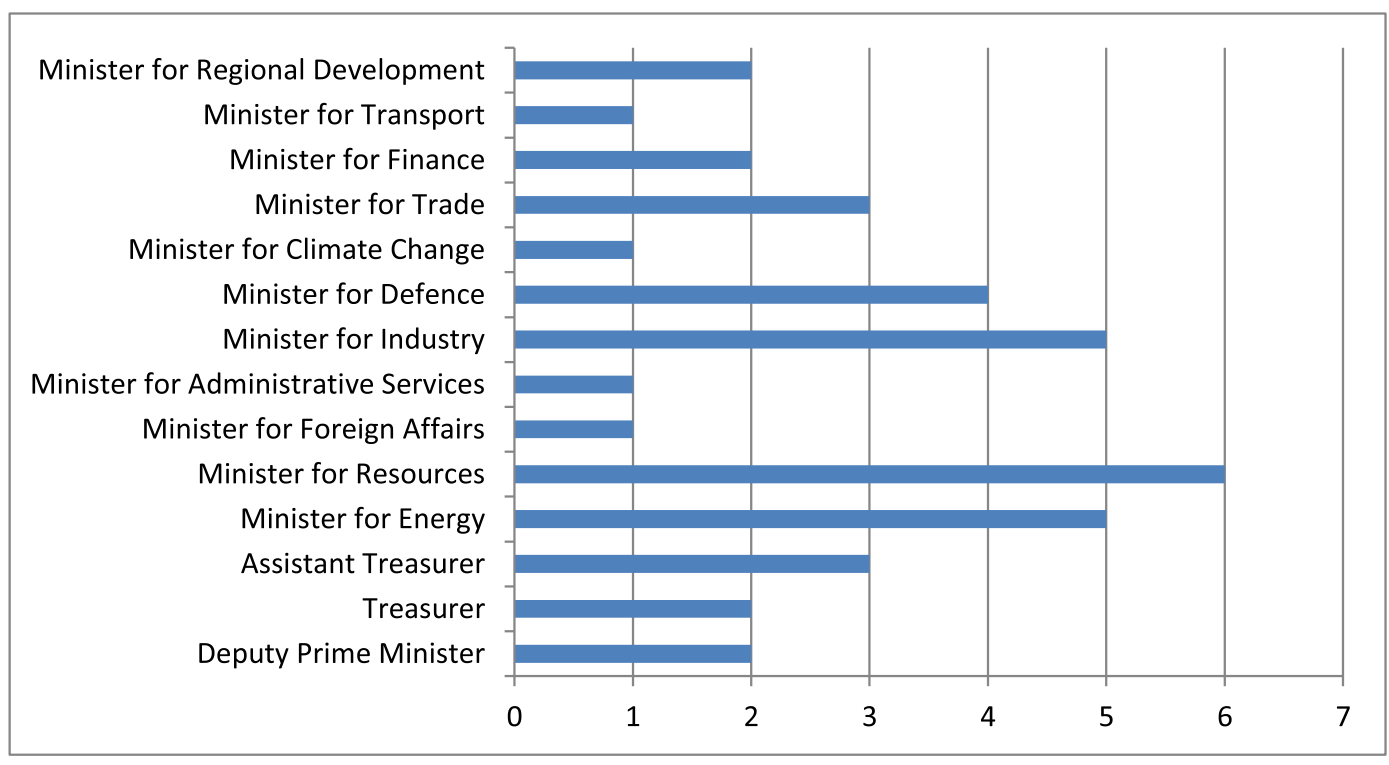

Fig. 5. Ministerial positions of federal politicians with fossil fuel employment relations.

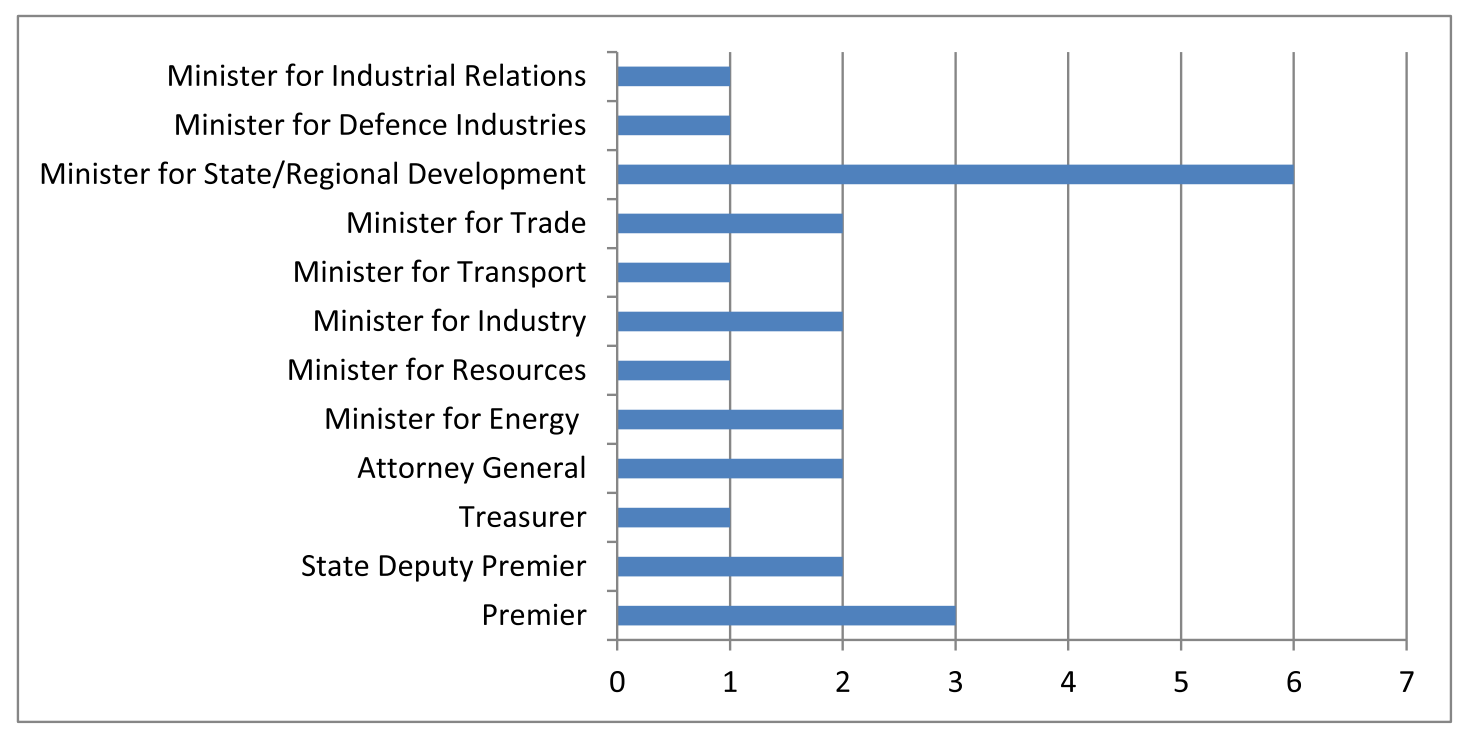

Fig. 6. Ministerial positions of state \& territory politicians with fossil fuel employment relations.

the majority are corporate board positions, followed by lobbying roles and a handful of consultancies. These are represented in Fig. 7. Again, because many of the politicians concerned have occupied more than one such position, the total numbers exceed the number of politicians. The 38 politicians in the database have occupied five positions as consultants, 27 positions for lobbying companies, and 37 positions as company directors and chairs: an average of almost two per person. Six of the 38 were founding members of lobbying firms. The fossil fuel companies and peak industry bodies for which they filled board positions are represented in Fig. 8. Twenty-four of the executive positions they occupied were with 18 entities: 15 fossil fuel companies and three peak industry bodies. Nine of these companies predominantly traded in coal, two in gas and two in oil. Only four of these entities recruited more than one politician on their boards, all of whom were former senior ministers. The entities concerned were Guildford Coal, Whitehaven Coal, Woodside Petroleum and the Australian Petroleum Production and Exploration Association (APPEA). The nine lobbying firms which have employed or been founded by former politicians are represented in Fig. 9.

Turning now to an analysis of the 119 political staffers and senior bureaucrats in the second database, we see there are 47 Liberal staffers, five LNP staffers, ${ }^{7}$ seven Nationals staffers and 37 Labor staffers, as well as 23 staffers of indeterminate political allegiance [Fig. 10]. The criteria for associating these individuals with particular political parties were if they had served in some official party capacity, and/or if they had

\footnotetext{
${ }^{7}$ The LNP is the coalition of the Liberal and National parties, which only exists in Queensland.
} 


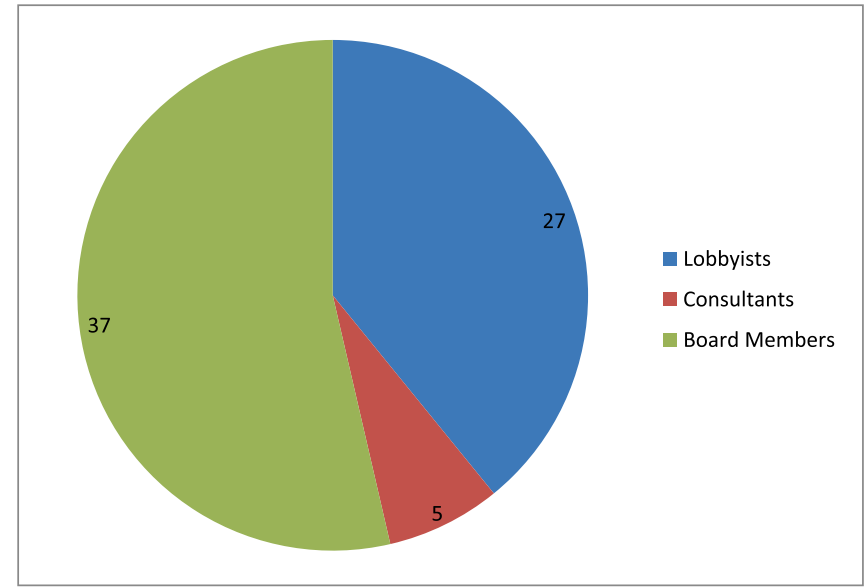

Fig. 7. Federal \& state ministers post-political employment as lobbyists, consultants \& board members for fossil-fuelled firms. worked as staffers for only the Coalition or Labor. Once again, we can see that the number of Coalition staffers with employment links to the fossil fuel industry is almost twice that of Labor staffers. Fig. 11 shows the jurisdictions in which the Coalition staffers and bureaucrats were employed. Fig. 12 shows the jurisdictions in which the Labor staffers and bureaucrats were employed. In both cases, most of the individuals concerned acted in multiple positions, and many served in more than one jurisdiction. In both cases, the vast majority of these people worked for the Federal Government, but many of them had also worked in NSW and Queensland, the richest states for fossil fuel resources. Only a handful had worked in other states or territories.

Figs. 13 and 14 provide breakdowns of the positions that the Coalition and Labor staffers and bureaucrats occupied while in public office. Once again, many of them performed multiple roles. Policy advisors, party executives, media advisors and chiefs of staff figure prominently among the Coalition operatives who have moved between the fossil fuel sector and public office (Fig. 13). Of the 143 substantive positions documented, 121, or 85 percent of the total, were in one or more of these categories. The profiles of the Labor operatives are somewhat different, with chiefs of staff and policy advisors to ministers featuring the most

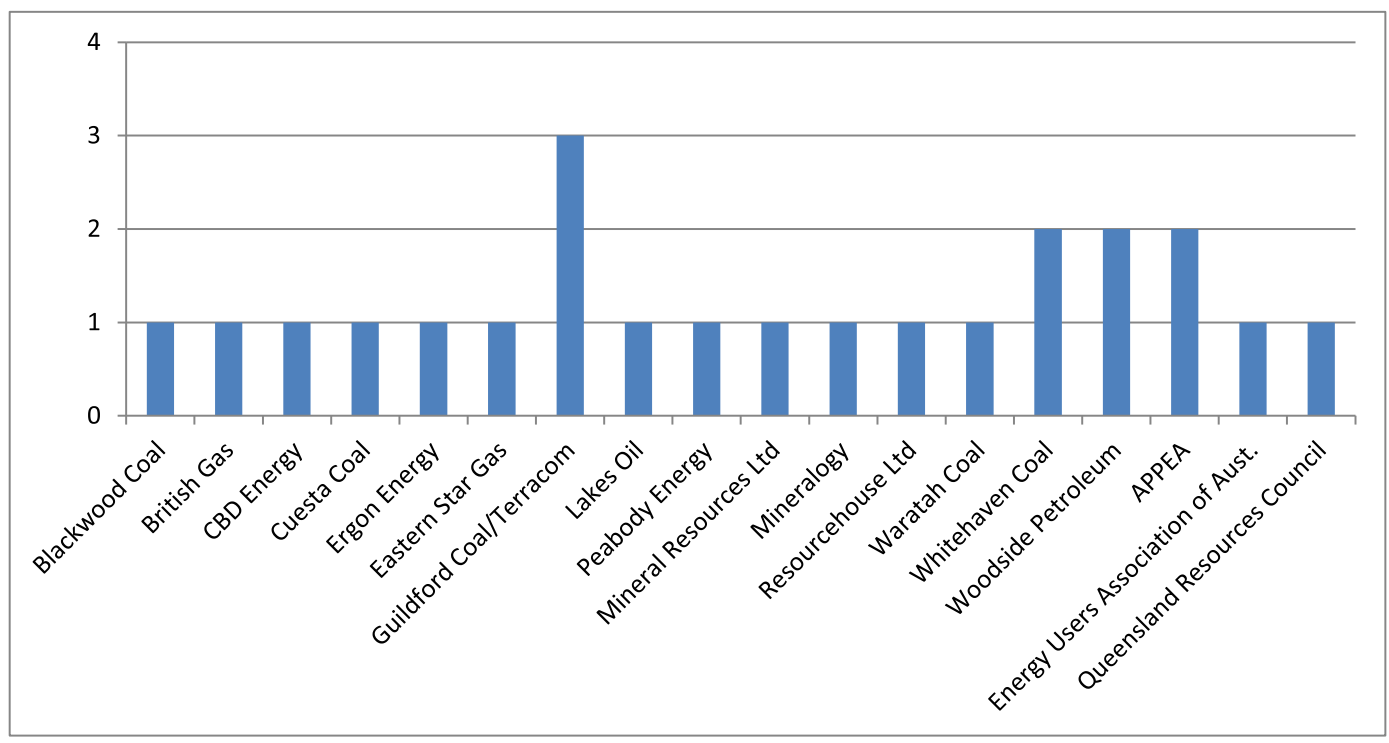

Fig. 8. Eighteen fossil fuel companies and peak industry bodies for which former politicians filled board positions.

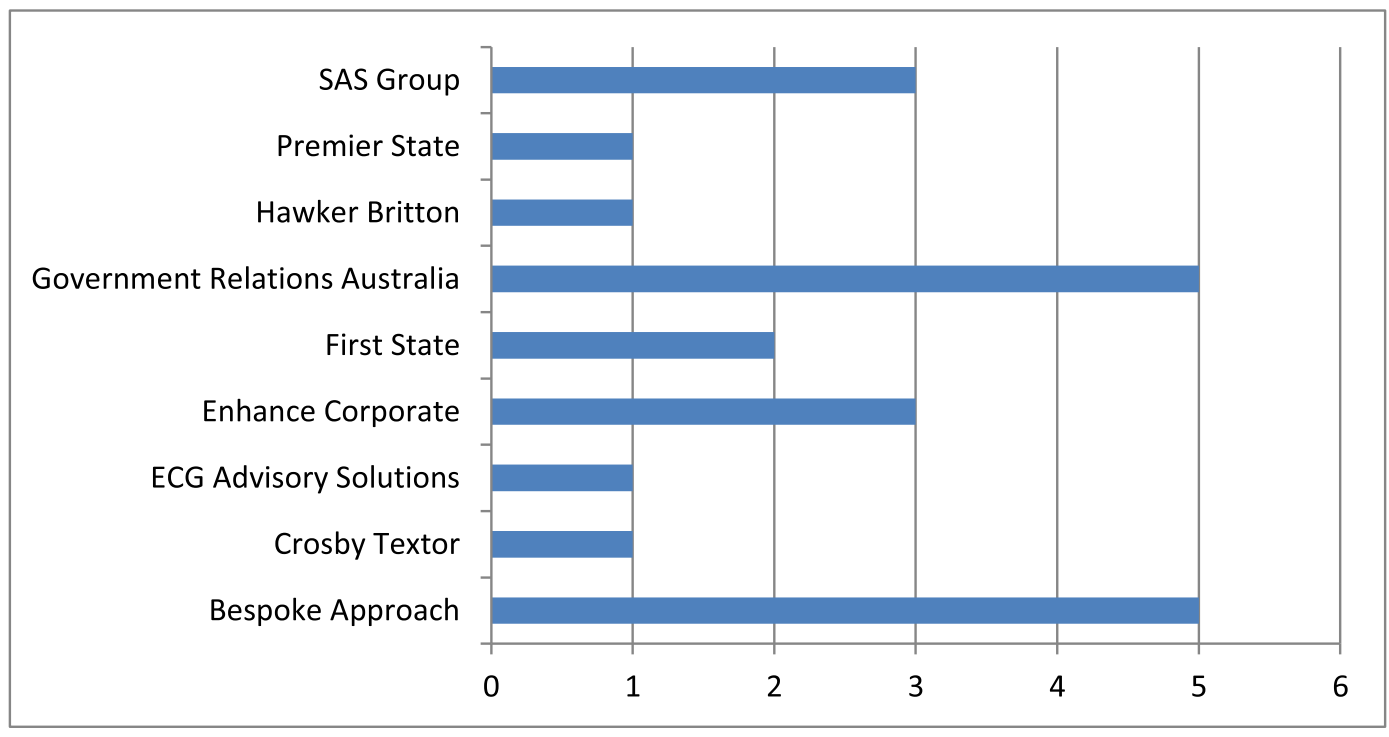

Fig. 9. Nine lobbying firms with fossil energy clients \& former politicians in their employ. 


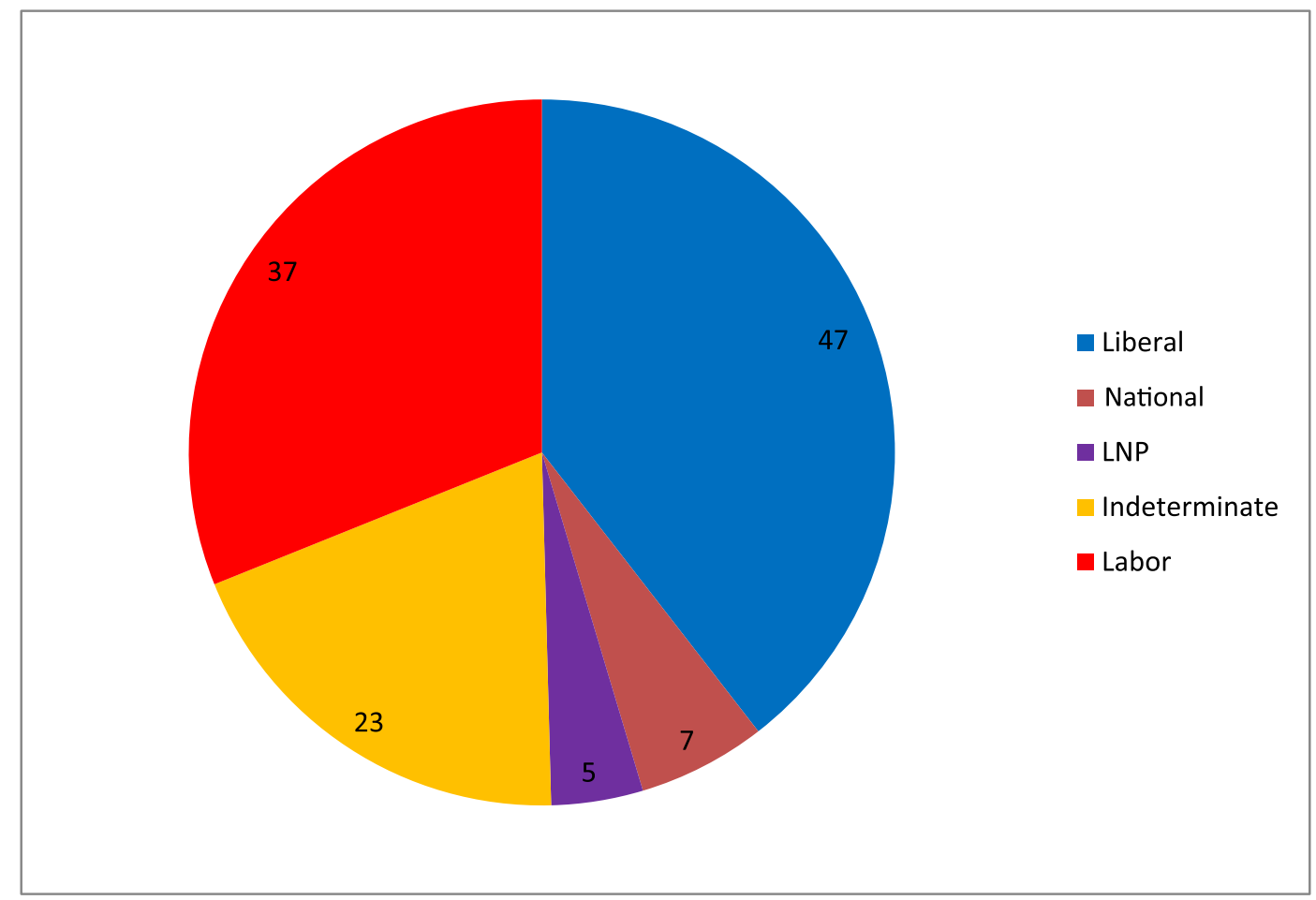

Fig. 10. Political party allegiances of 119 ministerial staffers \& senior bureaucrats employed by fossil fuel firms \& peak industry bodies.

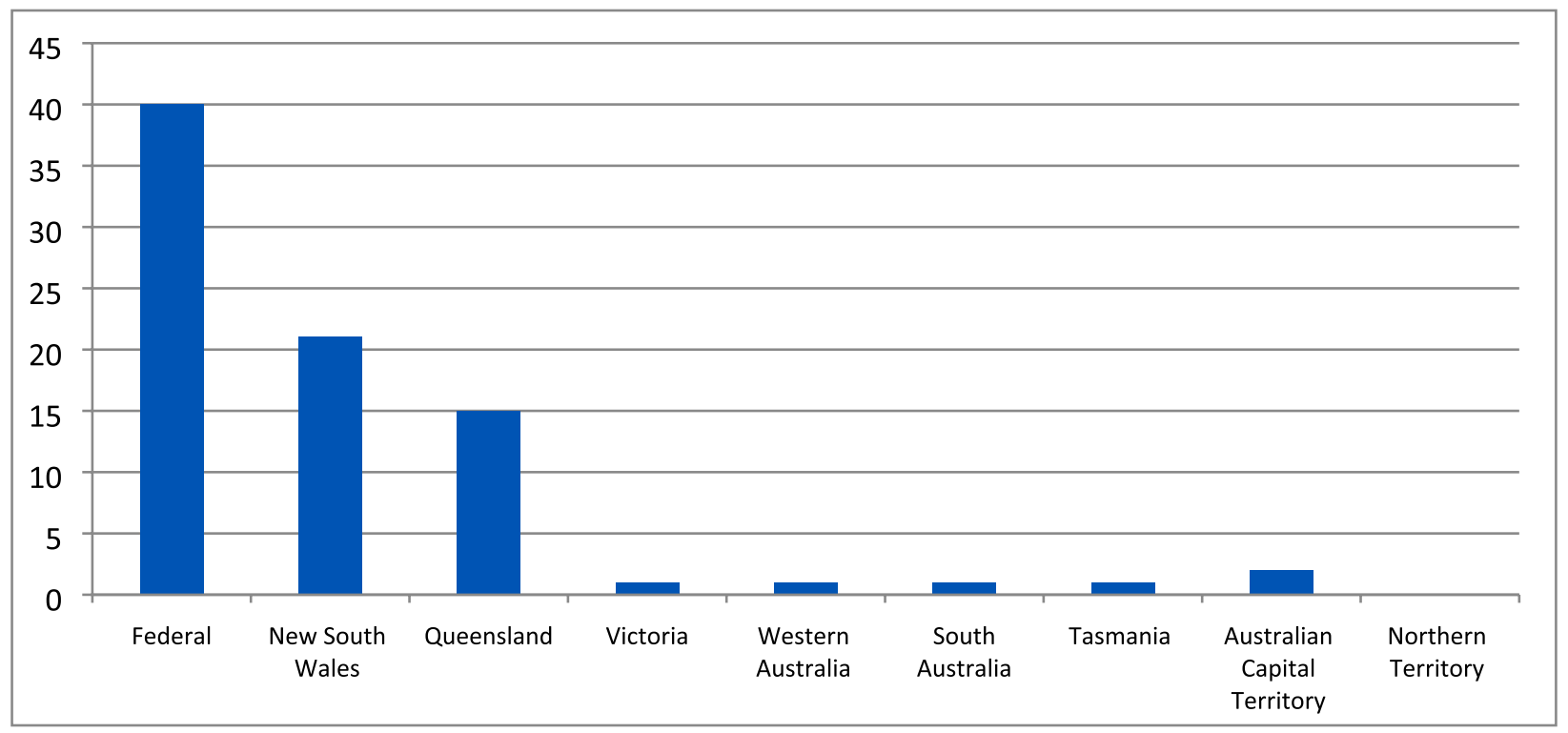

Fig. 11. State, territory \& federal jurisdictions in which 59 Coalition political staffers \& senior bureaucrats served with employment links to the fossil fuel industry.

prominently, followed by media advisors to ministers and the executives of other government departments (Fig. 14). Of the 85 substantive positions identified, 61 , or 72 percent of the total, were in one or more of these categories. Unsurprisingly, those with direct experience in the energy, resources, trade and industry portfolios figure prominently among all of these groups. Only a handful of the individuals concerned did not have some kind of direct experience in these portfolio areas. It should also be noted that all of the individuals in the 'indeterminate' 


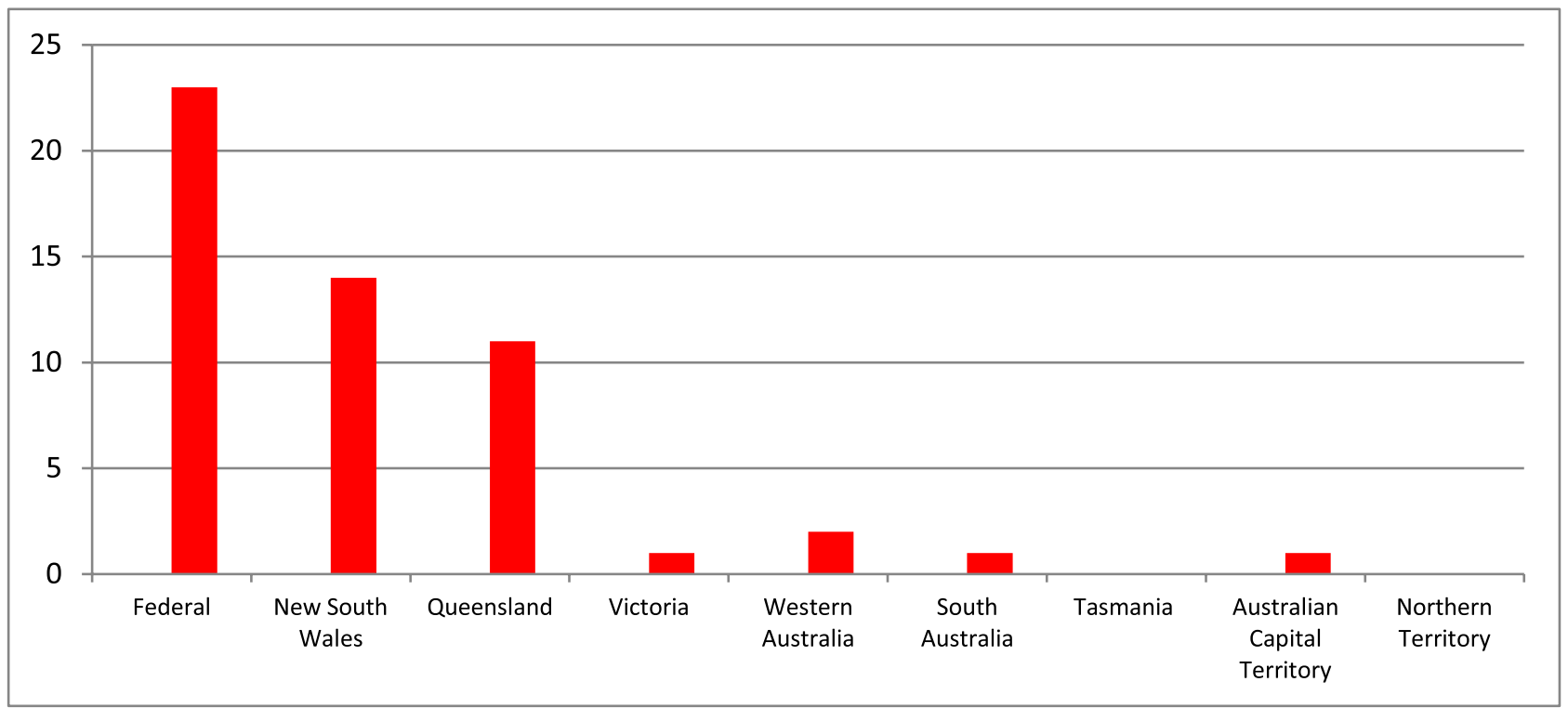

Fig. 12. State, territory \& federal jurisdictions in which 37 Labor political staffers \& senior bureaucrats served with employment links to the fossil fuel industry.

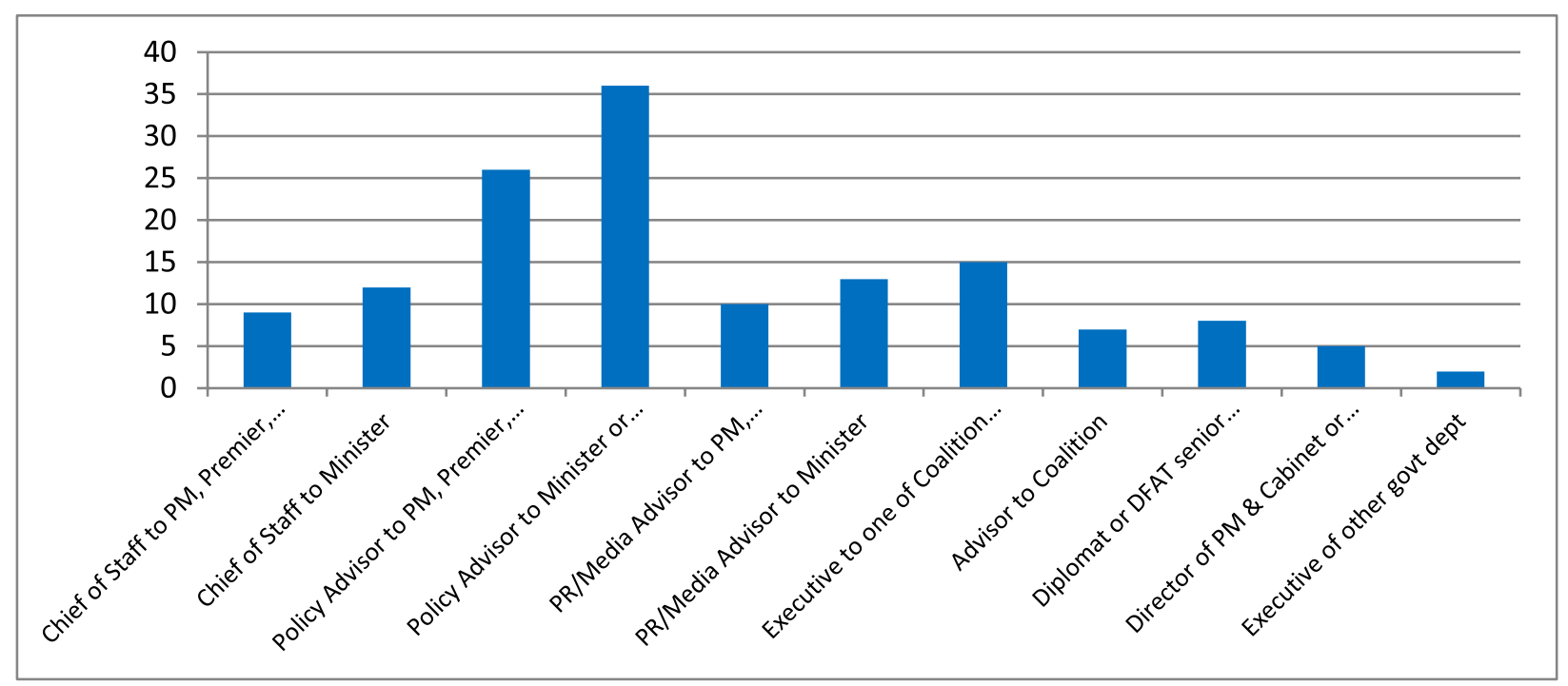

Fig. 13. Official government positions held by Coalition staffers \& senior bureaucrats with employment links to the fossil fuel industry.

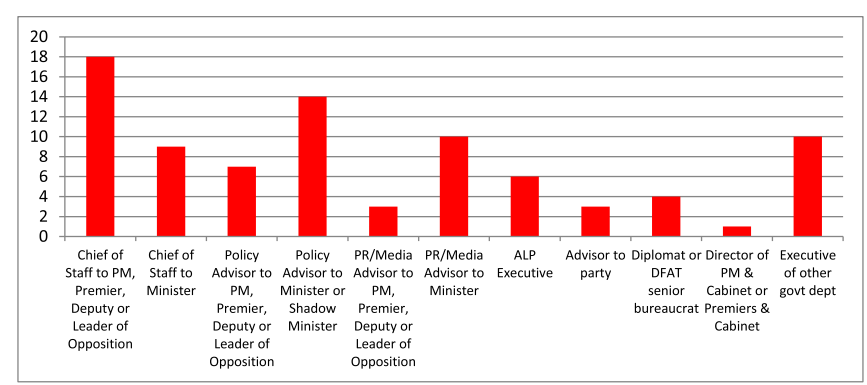

Fig. 14. Official government positions held by Labor staffers \& senior bureaucrats with employment links to the fossil fuel industry. category served as senior bureaucrats for federal and/or state government departments. All of them served in at least one of the aforementioned portfolio areas or a central policy and planning agency.

Figs. 15-17 show the number of positions that ALP, Coalition and other staffers and senior bureaucrats occupied as lobbyists, consultants and/or industry employees. ${ }^{8}$ Fig. 15 correlates lobbying firms and consultancies with fossil energy clients and the number of positions held in those firms by current or former political staffers and senior bureaucrats. Five of these firms stand out with five or more ex-political staffers working for them, four of which are bipartisan in their employment, but three of which favour the Coalition. Twelve of the 22 companies represented only employed former Coalition staffers, and four employed only former Labor staffers, indicating their party political

\footnotetext{
${ }^{8}$ Fourteen of the 91 Coalition and Labor staffers worked as journalists prior to working as staffers and in the fossil fuel and resource industries (15\%). Most of the Coalition-linked journalists worked for the Murdoch-controlled outlets, while most of the ALP-linked journalists worked for the Fairfax Group.
} 


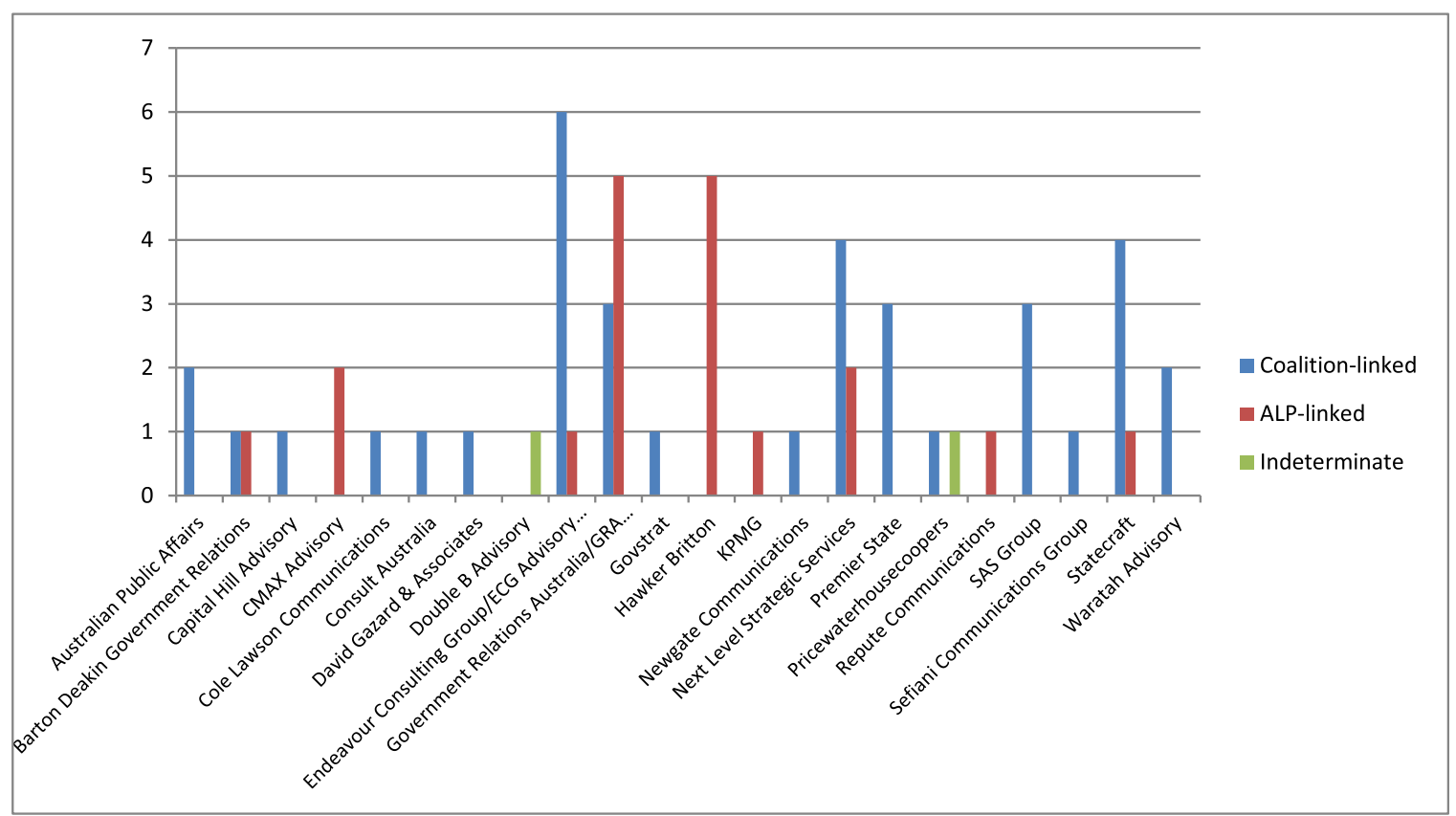

Fig. 15. Lobbying firms \& consultancies with fossil energy clients \& number of positions held by current or former political staffers \& senior bureaucrats.

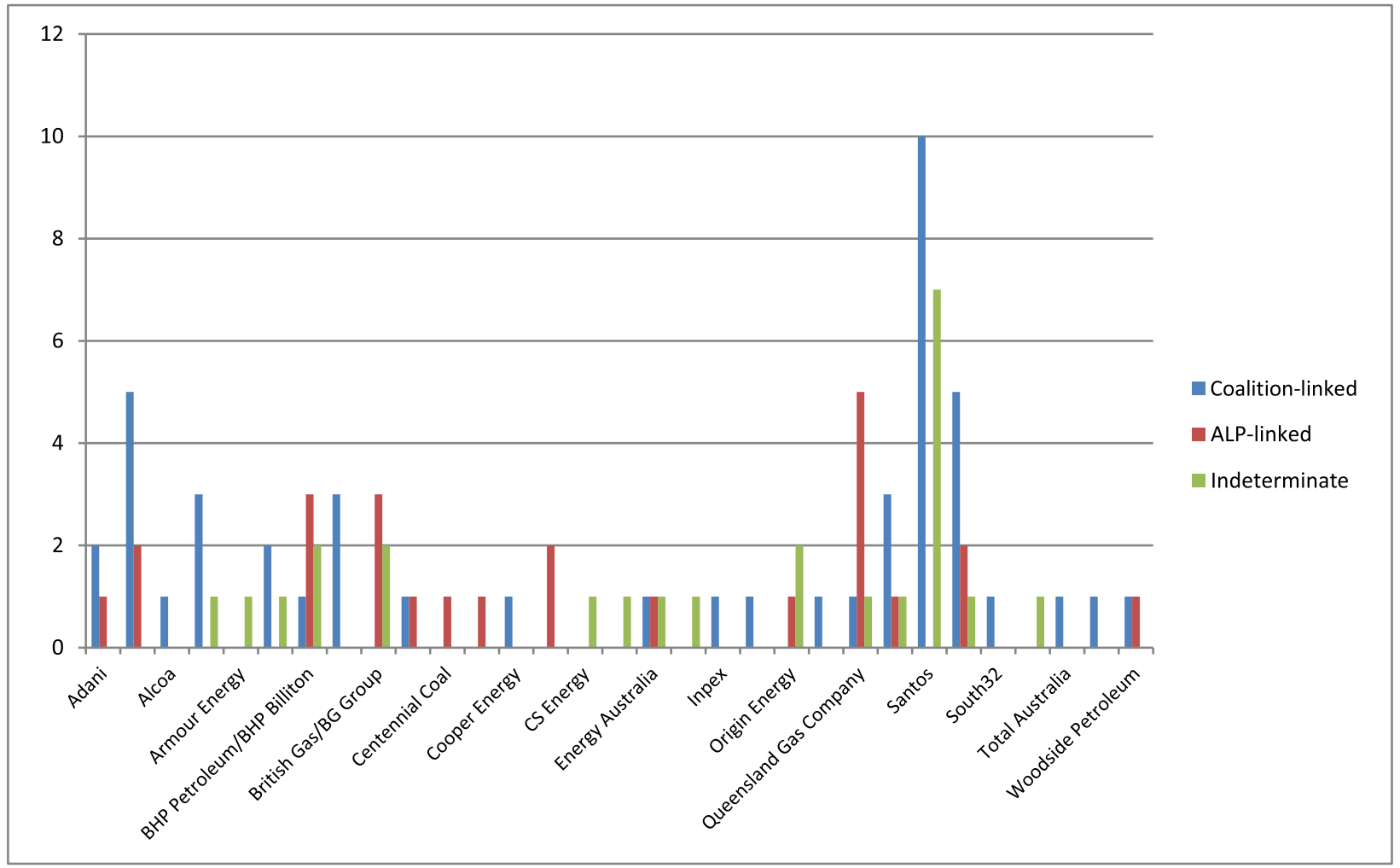

Fig. 16. Fossil-fuelled firms \& number of positions held by current or former political staffers \& senior bureaucrats.

affiliations. Only two of the 28 former senior bureaucrats of indeterminate political affiliations worked for lobbyists or consultancies.

Fig. 16 documents fossil-fuelled firms and the number of positions held by current or former political staffers and senior bureaucrats. Almost all of the biggest employees in this instance are companies heavily invested in the gas industry, i.e. AGL, BHP Petroleum/BHP
Billiton, British Gas/BG Group, Origin Energy, Queensland Gas Company, Santos and Shell Australia. Given that the period from 2007 to the present has seen the largest and most rapid historic expansion in the industry (Fig. 2), clearly all of these firms were ensuring they had ample inside knowledge and connections to government.

Fig. 17 documents fossil-fuelled industry peak bodies and the 


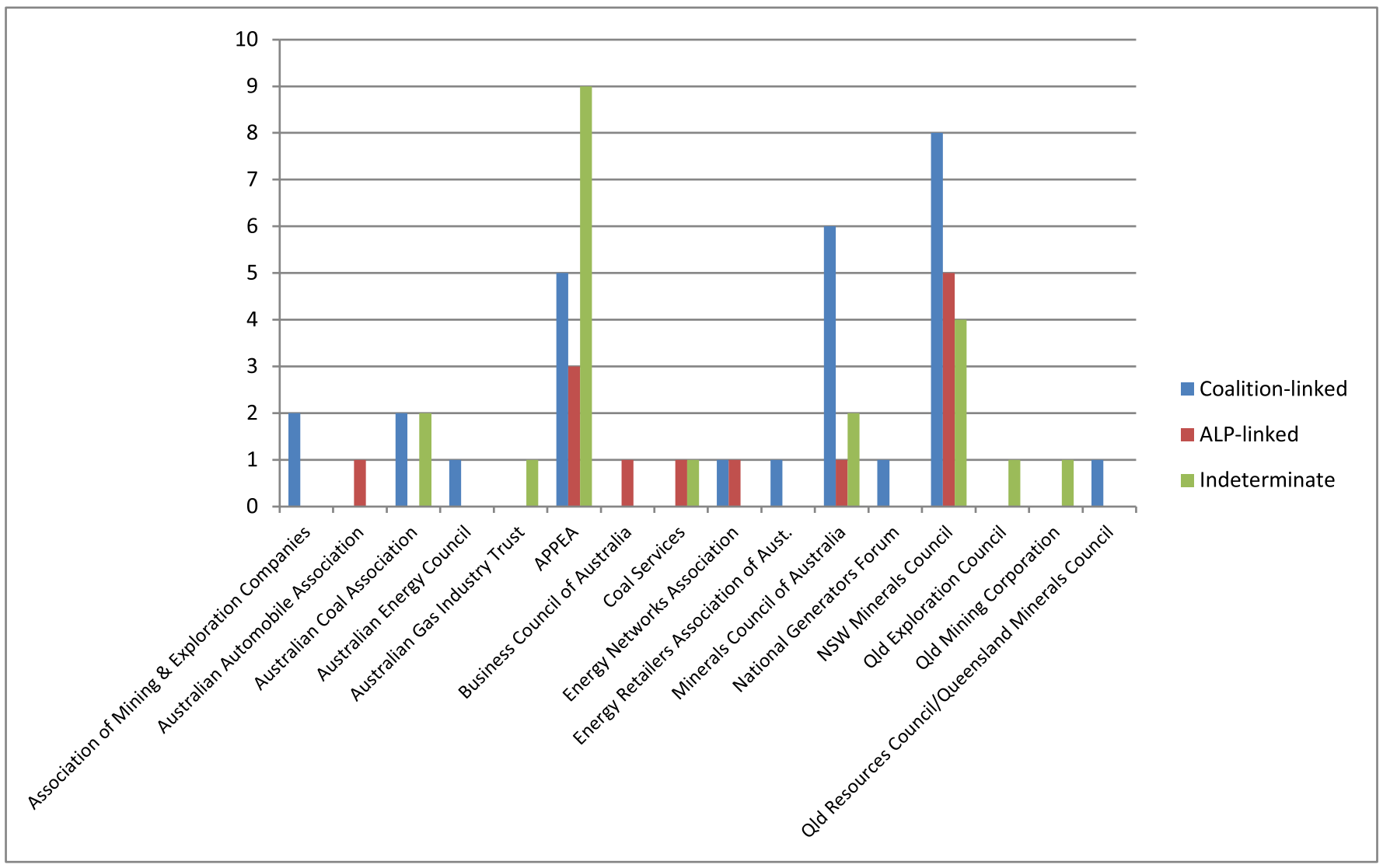

Fig. 17. Fossil-fuelled industry peak bodies \& number of positions held by current or former political staffers \& senior bureaucrats.

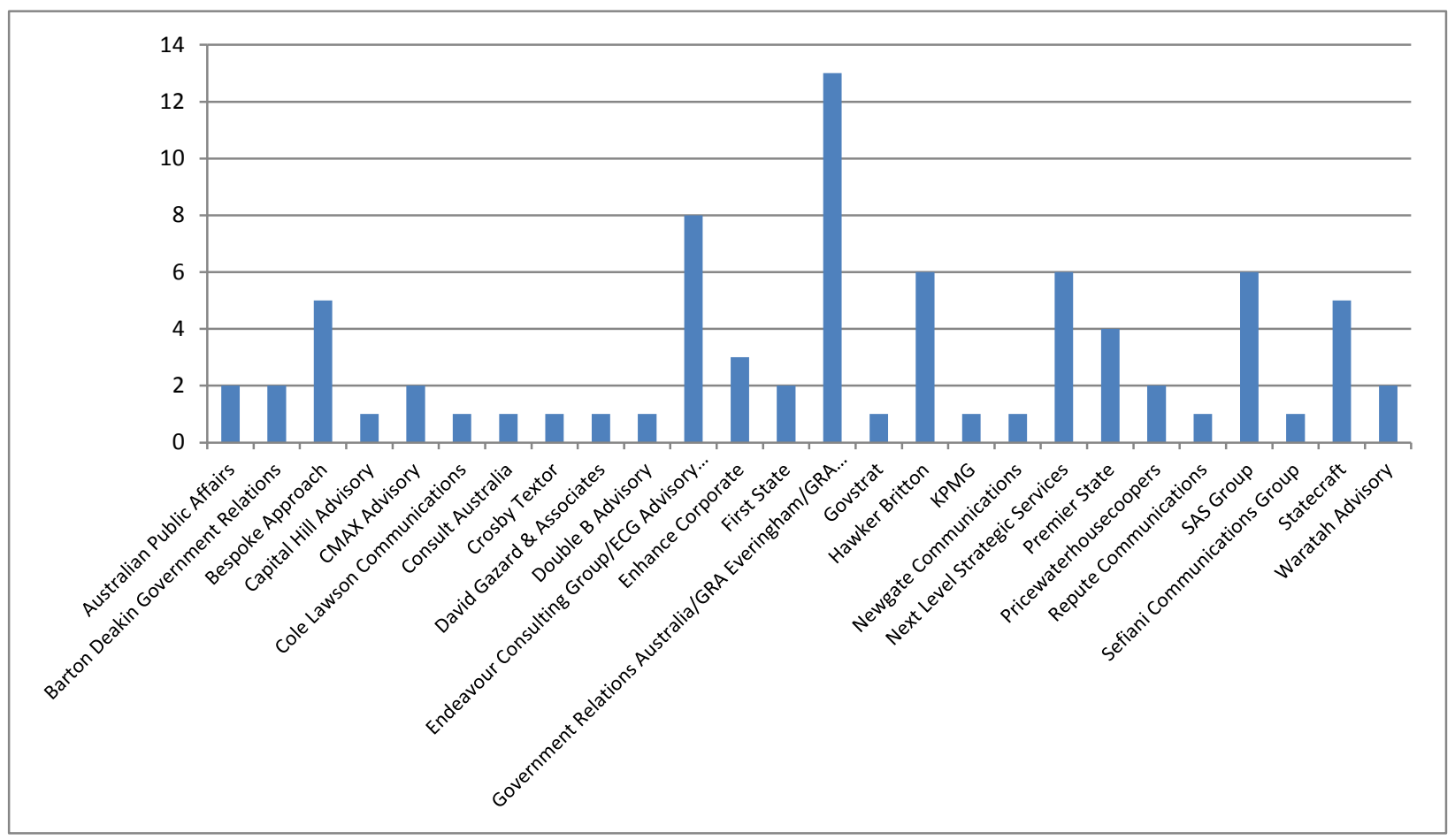

Fig. 18. Total no. of positions in lobbying firms \& consultancies occupied by current \& former politicians, staffers $\&$ senior bureaucrats. 


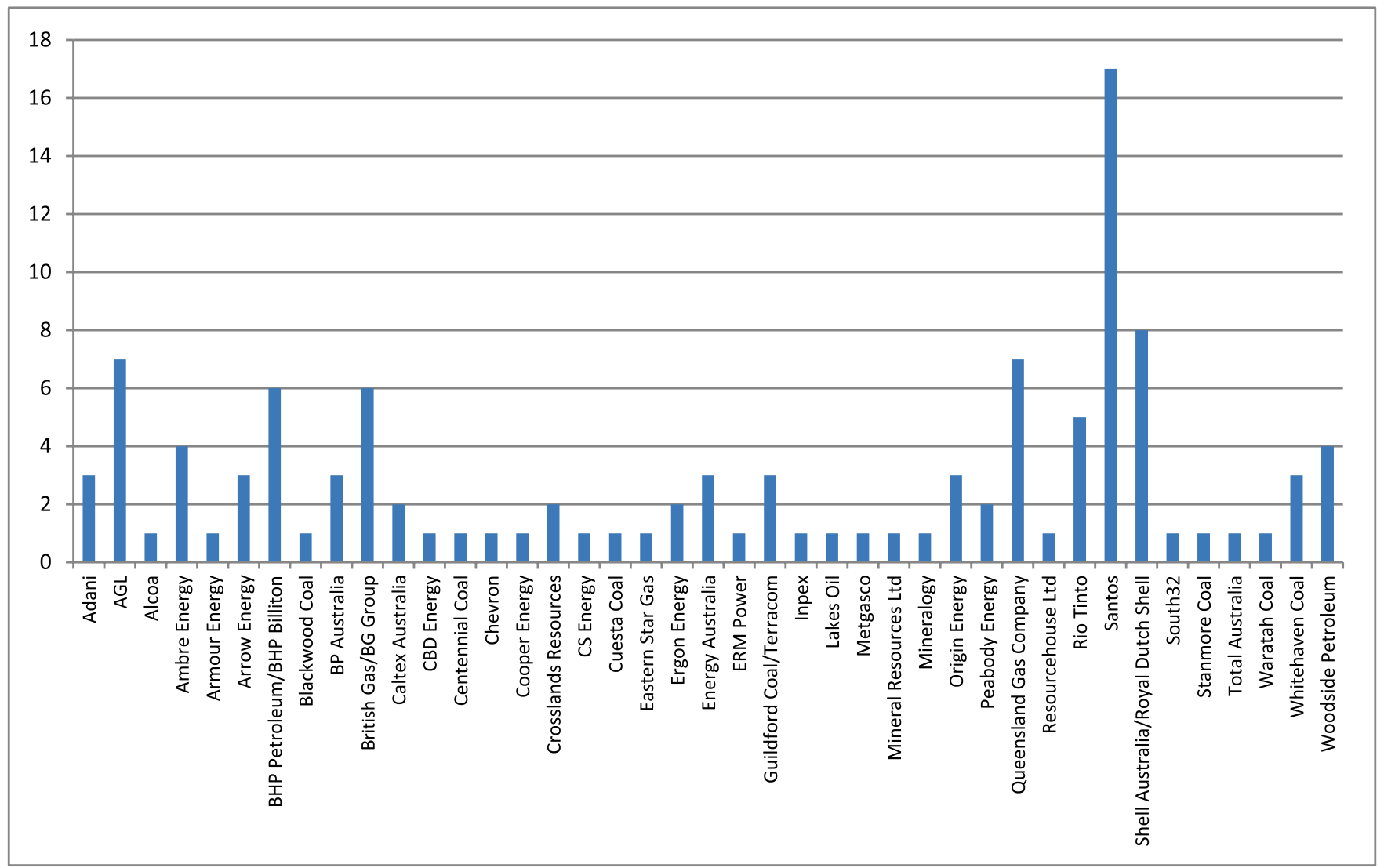

Fig. 19. Total no. of positions in fossil-fuelled firms occupied by current \& former politicians, staffers \& senior bureaucrats.

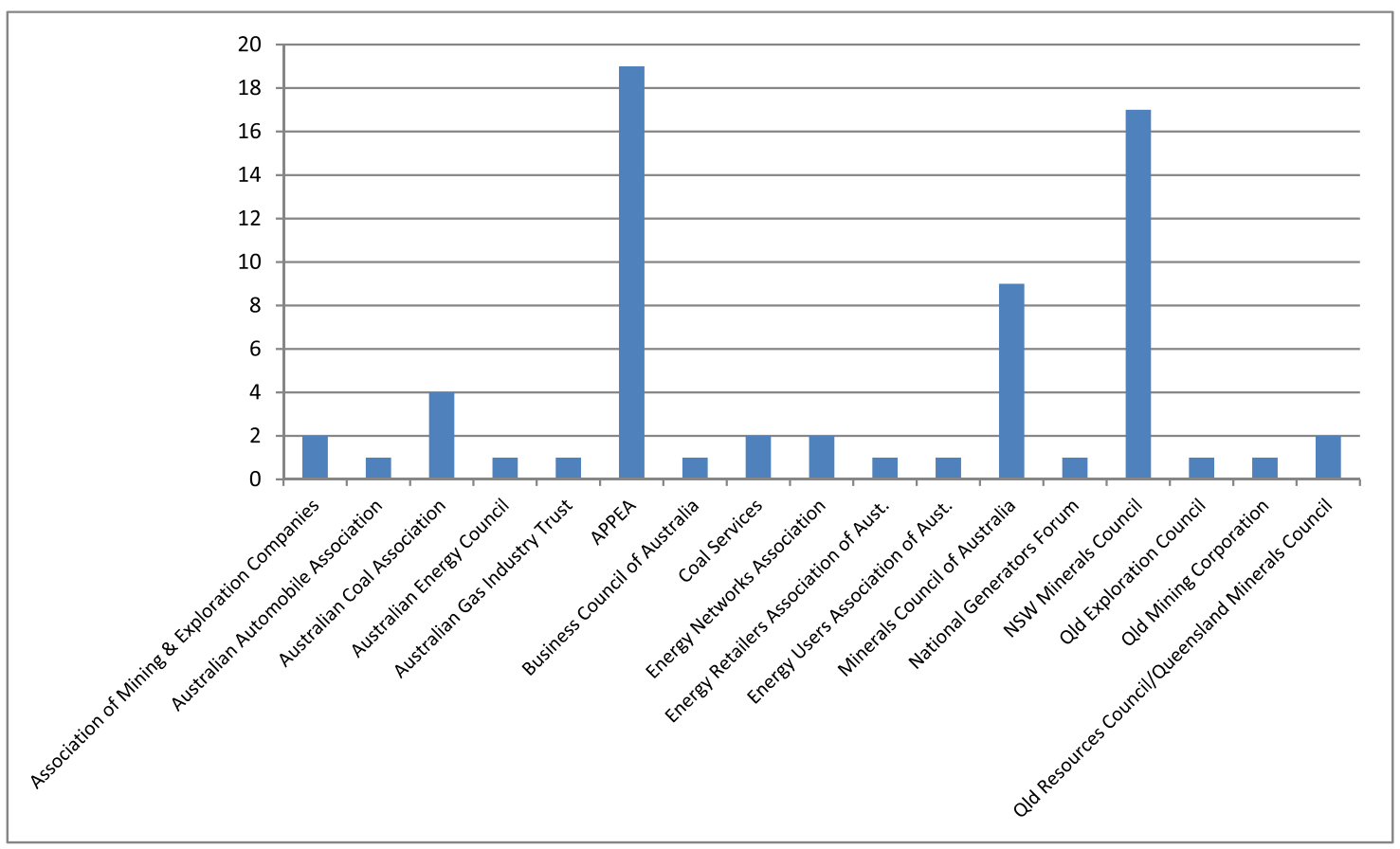

Fig. 20. Total no. of positions in peak industry bodies occupied by current $\&$ former politicians, staffers $\&$ senior bureaucrats. 


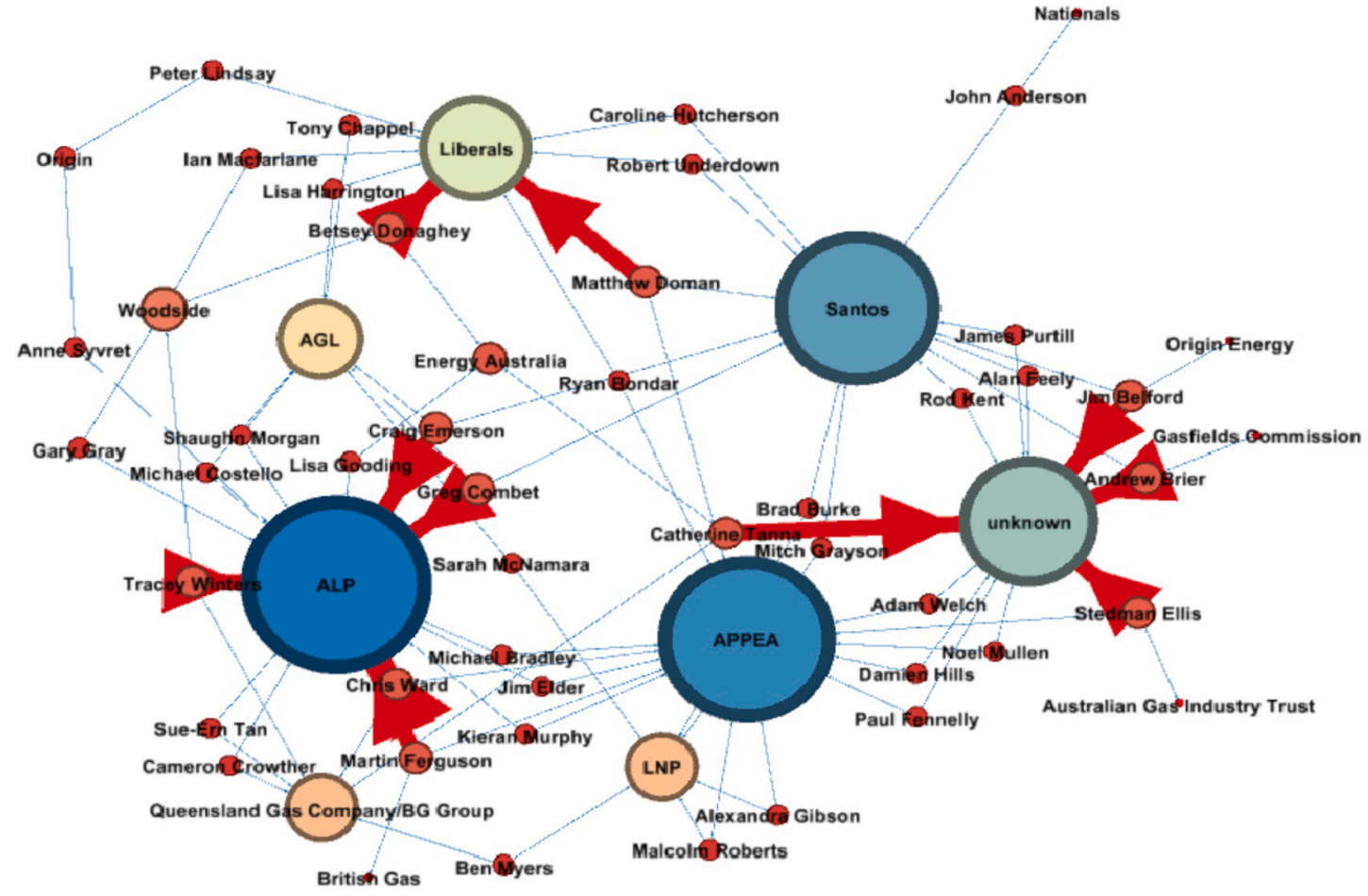

Fig. 21. Gas industry network with APPEA \& political parties.

number of positions held by current or former political staffers and senior bureaucrats. Three industry peak bodies, APPEA, the Minerals Council of Australia and the NSW Minerals Council have been clearly preoccupied with employing individuals from all three groups (i.e. the Coalition, ALP and indeterminate), with the Coalition clearly favoured in each case. APPEA appears to have seen an additional advantage in employing nine former senior industry bureaucrats.

Figs. 18-20 collate all of the information contained in both databases for all individuals and relationships recorded. Fig. 18 collates all of the data on lobbying firms and consultancies. It shows that the vast majority of the 79 positions filled by these individuals were concentrated in half a dozen companies, all of which were founded by former senior politicians from the ALP and Coalition. Fig. 19 compiles all the employment data for fossil-fuelled firms. It clearly demonstrates that the largest number of former senior politicians, staffers and bureaucrats have been employed by major players in the rapidly expanding gas industry. In descending order, these are Santos, Shell Australia, AGL, Queensland Gas Company, BHP Billiton and British Gas/BG Group. Fig. 20 compiles all the data for industry peak bodies. Once again, three major players stand out: APPEA, the NSW Minerals Council and the Minerals Council of Australia, all of which are well-documented to promote climate change denial and disinformation concerning the relative merits of renewable energy and action on climate change. Readers who are interested in learning the details concerning the quantity and timing of lobbying expenditure by these peak industry bodies, as well as the timing and quantity of donations flowing from the fossil fuel and resource industries to the ALP and Coalition, are directed to Hanna Aulby's research for TAI and the Centre for Public Integrity. Aulby's research clearly demonstrates that all the peak industry bodies ramped up their activities and expenditure following the federal election of the ALP between 2009 and 2013. They all vigorously campaigned against Labor's relatively modest climate change and renewable energy policies, and again ramped up their activities and expenditure when Liberal PM Malcolm Turnbull proved insufficiently compliant to their interests [191,192].

Figs. 21 and 22 are social network diagrams of some of the relationships documented in the two databases which have been rendered with Gephi open source software. Fig. 21 illustrates the covert gas industry network, illustrating the employment relationships between the Coalition (Liberals, Nationals, LNP) and ALP, and prominent players in the industry, including Santos, APPEA, AGL, the Queensland Gas Company/BG Group, Woodside, Origin Energy, the Gasfields Commission and the Australian Gas Industry Trust. The size of each node indicates the number of connections to other entities and individuals. The red arrows indicate the strength of the relationships between the three main political groupings (Liberals, ALP, unknown) and the individuals linked to gas industry entities. It is clear from this diagram that the ALP, APPEA and Santos are the dominant political players in this network. This is borne out by the levels of political donations flowing to the ALP from the gas industry, as documented in Figs. 23-25.

Fig. 22 illustrates the employment relationships between dominant industry players in coal, oil and gas and associated politicians, staffers and senior bureaucrats, together with the latter groups' political affiliations. When these relationships are aggregated, the Liberals are undoubtedly the most prominent players in the network, closely followed by the ALP, APPEA, Santos, the Minerals Council of Australia and the NSW Minerals Council. AGL, Shell, QGC/BG Group and Rio Tinto are other major players. Once again, the blue arrows indicate the strength of the relationships between the three main political groupings (Liberals, ALP, unknown) and the individuals linked to fossil industry entities. All of these observations are confirmed by the data contained in the previously analysed charts.

Four of the top ten fossil fuel political donors in Australia between 2015 and 2019, i.e. Woodside, Santos, Chevron and Origin Energy (Figs. 23-25) figure prominently in the previous analysis. It is no coincidence that they are also among the top tax avoiders in the resource and energy industries, bearing in mind that the top tax payers in both sectors only paid on average 5 percent of their total revenue in income tax over this four year period. Woodside paid 5.5 percent on its $\$ 21.8$ billion in total revenue, Santos paid 0.02 percent on its $\$ 14.9$ billion in total revenue, and Chevron paid zero income tax on $\$ 10.5$ billion in total 


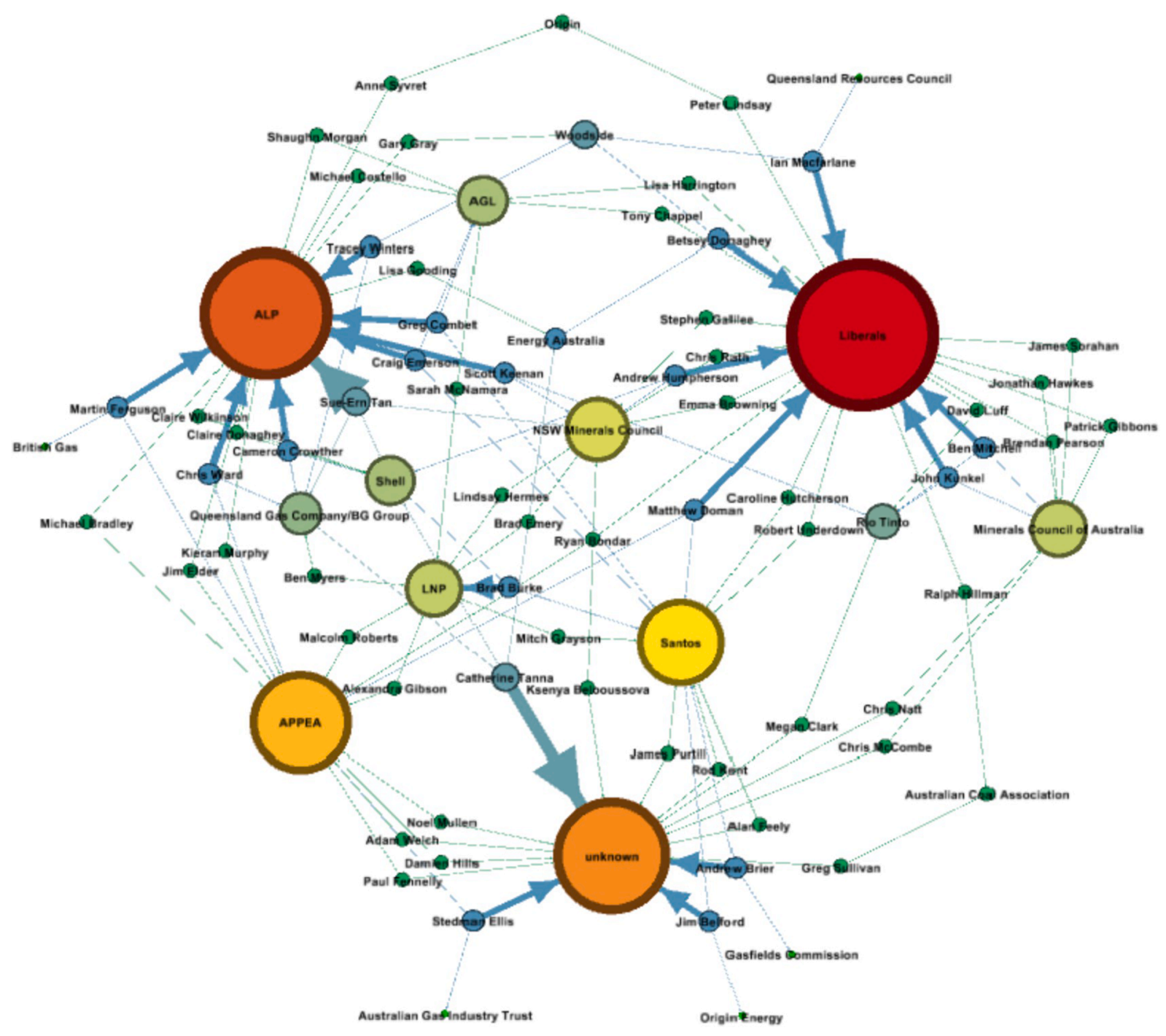

Fig. 22. Peak fossil industry network \& political affiliations.

revenue. Last financial year, Origin Energy also paid zero income tax on its disclosed $\$ 7.2$ billion revenue with project partners ConocoPhillips and Sinopec. ${ }^{9}$ Santos likewise paid zero income tax last financial year on $\$ 4.3$ billion in total revenue, as did Woodside with $\$ 8.2$ billion total revenue and $\$ 2$ billion in taxable income. Two of Shell's subsidiaries, QGC Upstream Holdings and Shell Upstream Holdings also paid zero income tax on $\$ 4$ billion and $\$ 5.5$ billion respectively [193].

All of these companies are dominant players in Australia's gas industry cartel - together they donated more than $\$ 2.4$ million to the Coalition and ALP, while two other major donors, i.e. Bluescope Steel and Mineral Resources, are major consumers of gas. The period covered by these tax figures encompass two federal elections and several state and territory elections. Between 2015 and 2019, Woodside donated more than $\$ 1$ million and Santos around $\$ 570,000$ (Fig. 23), most of which went to the ALP (Figs. 24 and 25). The ALP currently controls most of the sub-national governments holding major gas resources in Australia, i.e. Queensland, WA and the NT [194]. Given the generous political donations which the ALP has received from Woodside, Santos and other major gas producers and consumers over the last several years,

\footnotetext{
${ }^{9}$ ConocoPhillips is also the beneficiary of the helium and gas concessions provided by the Howard Government in the Timor Gap negotiations, which are the subject of ongoing legal challenges and corruption allegations [207].
}

and the extent to which it has successfully courted former Labor politicians and staffers, it is perhaps unsurprising that it remains supportive of the expansion of the gas industry in Australia and has shown no preparedness to demand they pay more income tax.

The clear preference for the ALP in the level of donations from Santos, Chevron and Origin for the period 2015 to 2019 is captured by recent research published by the Australian Conservation Foundation (ACF), which also shows that the coal industry's preferred donation recipient over the same period was the Liberal Party [194] (Figs. 23-25). What is most alarming about the lack of regulation of federal political donations, however, is the fact that more than half of the private incomes of the Liberal and Labor parties during the 2013 election could not be traced [195], while more than $\$ 100$ million flowed to them from anonymous donors in the 2018-19 financial year during which the most recent federal election was held. Federal political donation laws are so inadequate that the sources of more than $\$ 1$ billion in undisclosed income to the major parties since 1999 cannot be traced [196]. It is highly likely, therefore, given the revenues and wealth of the fossil fuel and resource extraction industries, that a significant proportion of this 'dark money' has come from these industries, ensuring their structural power to determine the parameters of government policy is maintained, and the sources of their power remain hidden from the public.

All of these data confirm the role of dominant capital in not only shaping, but controlling the way in which energy and climate policy has 


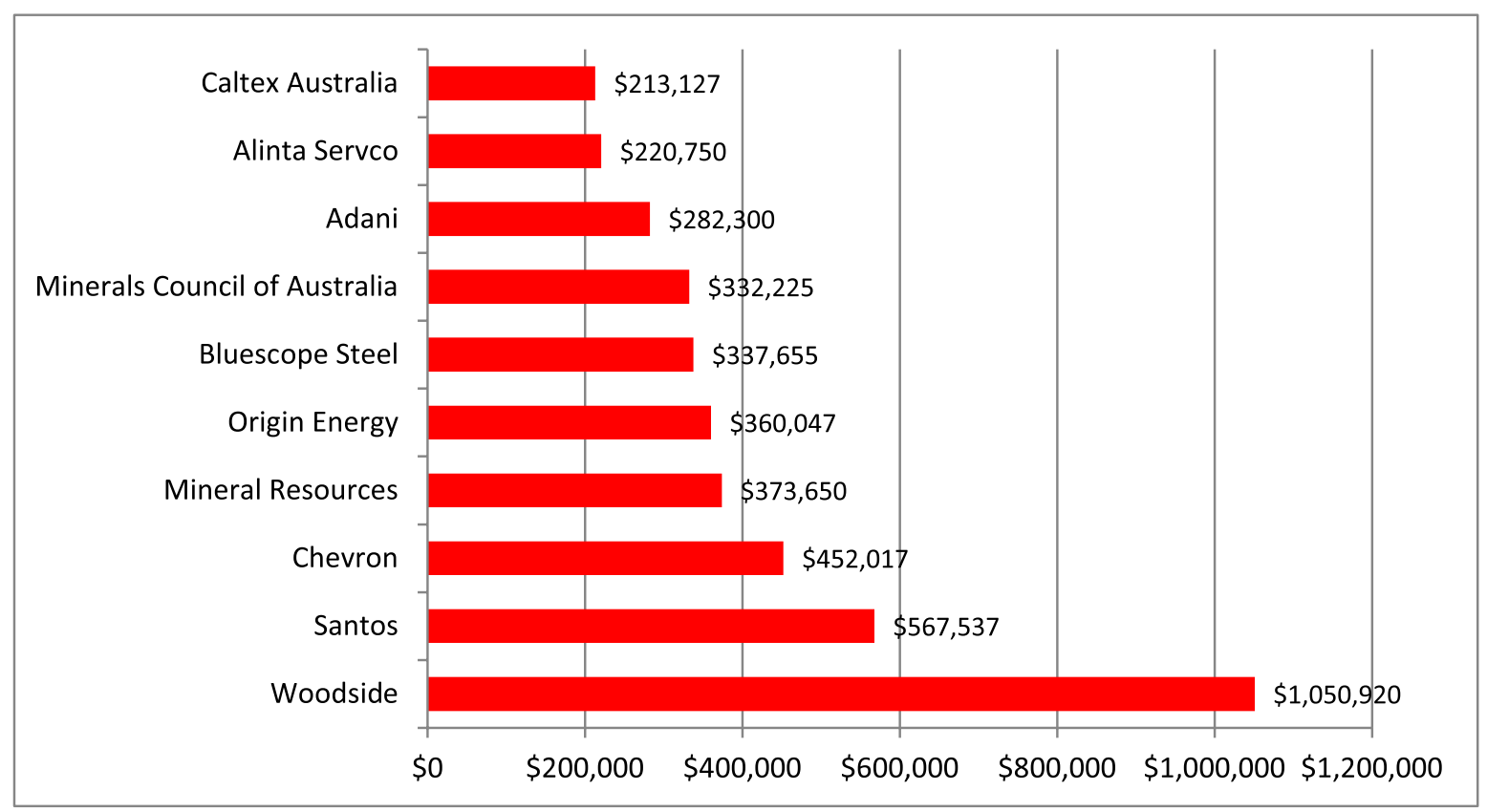

Fig. 23. Top 10 fossil fuel political donors in Australia, 2015-19. Source: Australian Electoral Commission/Australian Conservation Foundation.

Source: Australian Electoral Commission/Australian Conservation Foundation

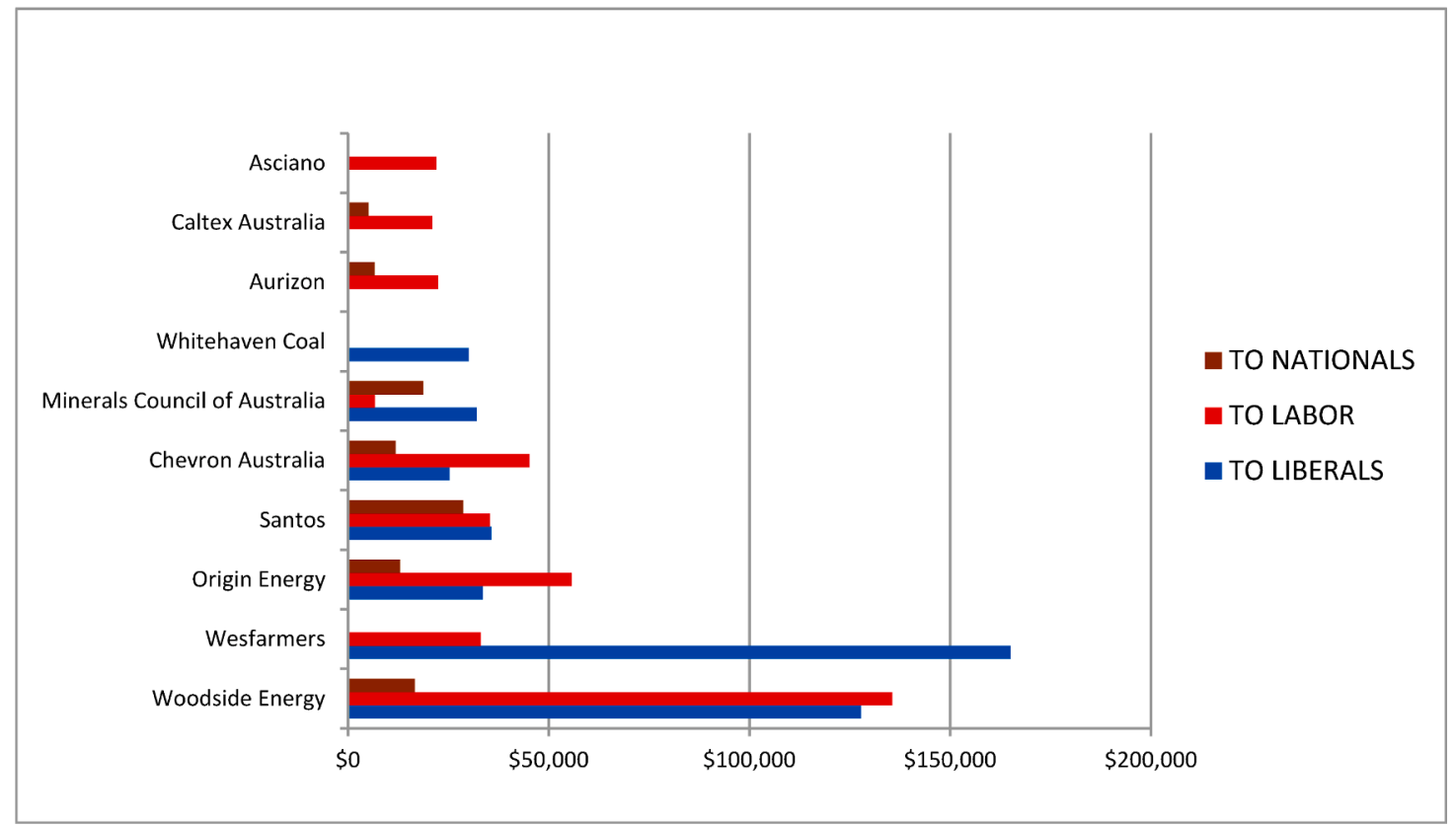

Fig. 24. Top 10 fossil fuel political donors \& donees in Australia, 2016-17. Source: Australian Electoral Commission/Australian Conservation Foundation.

developed in Australia over the last fifteen years. Indeed, it would be difficult to imagine more compelling data regarding that role in these two crucial areas of government policy. The gas industry has focused on the ALP, and the coal industry on the Coalition, a fact which is further supported by the kind of industry-friendly rhetoric senior politicians from both parties have publicly espoused for well over a decade. Both the ALP and Coalition have demonstrated their support for the oil industry by enabling it to continue to pay little or no income tax on new and existing oil and gas projects, and by failing to act on the majority of the issues identified in Table 5 which directly benefit the industry's market capitalization.

The evidence presented supports all of the theories outlined in
Section 3, i.e. economic-elite domination, biased pluralism, capital as power $(\mathrm{CaP})$ and para-politics. This conclusion is virtually inescapable if we compare this evidence to the core assumptions pertaining to each of these theoretical approaches.

The breadth and depth of the strategies identified above and the extraordinarily favourable economic and political outcomes they appear to have produced provide prima facie evidence for corporate state capture of Australian governments by the fossil fuel industry. The interests of corporations, business associations and professional groups with interests in preserving the status quo on energy and climate policy in Australia have consistently predominated over those of the 'average citizen' and mass-based interest groups. The majority of the indicators of 


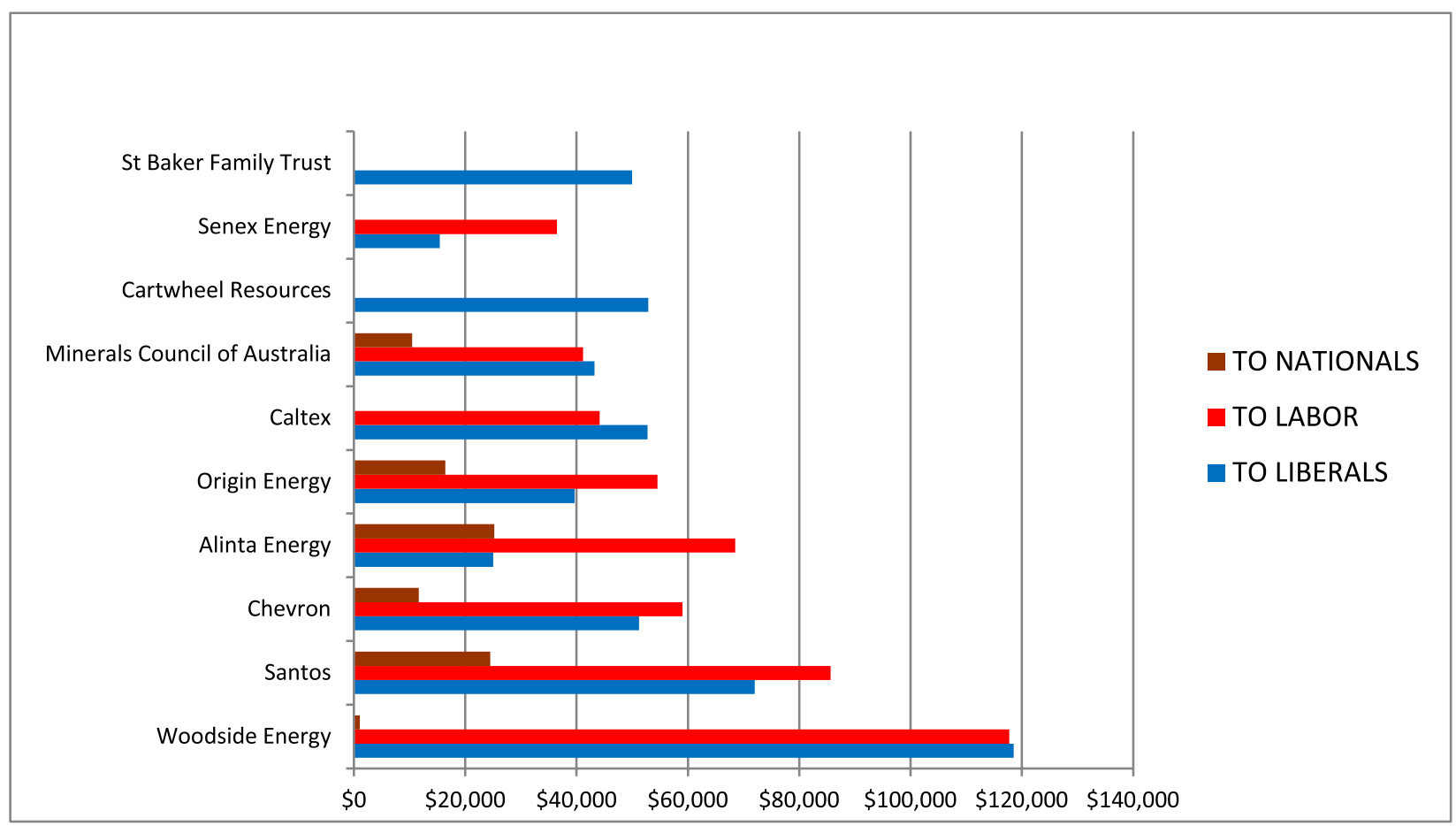

Fig. 25. Top 10 fossil fuel political donors \& donees in Australia, 2017-18. Source: Australian Electoral Commission/Australian Conservation Foundation.

corporate state capture identified in Table 5 have low public visibility, and the scope of conflict associated with them is largely restricted to a handful of environmental and social justice advocacy groups and their supporters in academia and civil society. These findings are consistent with economic-elite domination theory and biased pluralism.

Figs. 3-22 document the extent to which the social power networks occupied by the fossil fuel and resource extraction industries extend into and connect with the major political parties and key bureaucracies, jurisdictions and portfolio areas. These findings clearly support economicelite domination theories by documenting how individuals with high social status occupying key institutional positions in government, business and industry share common interests, backgrounds and social networks. This evidence also clearly supports CaP, because it demonstrates that economic elites in the fossil fuel and resource extraction industries have used their corporations' high levels of financialization and assetization to work through foundations, think-tanks, lobbying firms and other 'opinion-shaping apparatus' such as the Murdoch media to dominate government decision-making. This also constitutes clear evidence of biased pluralism, because a small corporate elite, primarily headquartered in the United States, has been able to consistently sideline democratic electoral processes and the wishes of the majority of Australians, who have repeatedly expressed their preference to rapidly decarbonise and reduce carbon emissions.

The structural power of dominant corporations in the electricity, coal, gas and oil industries and their peak industry bodies is exercised covertly through their control of the economic, political and policy agendas deemed legitimate by Australian governments. Their ability to structure these agendas to their political and economic advantage is achieved instrumentally over the major political parties through various forms of coercion via lobbying, political donations and the inside information obtained by revolving door operatives. All of these activities bias government decision-making to heavily favour corporate interests and therefore support the research of theorists of biased pluralism and economic-elite domination.

Para-political behaviour, or Machiavellian forms of sabotage, are common strategies for all of these entities and the individuals who serve them. When outright coercion following the instrumental power playbook has proven ineffectual, sabotage of existing or proposed policies is then pursued, as we have seen in Australia in relation to emissions trading, carbon pricing, the Solar Flagships Program, and many other progressive policy initiatives relating to energy and climate change in Australia. The ability of dominant capital to incapacitate or sabotage is a central feature of its power to control industrial development according to CaP.

All of the evidence canvassed above demonstrates the existence of structural biases in the institutions of government and various forms of 'soft corruption'. These findings complement those of researchers on the climate change counter-movement in North America [13-15,17-28], and of UK researchers on deep incumbency [29-33]. Consequently, if social scientists are serious in their commitment to understanding why such preferences find such consistent political expression, the methodological and theoretical toolkits we deploy cannot rely solely on the productive power of ideologies [146-148] or discourses [35,36] to explain these phenomena.

\section{Conclusion}

Australia has repeatedly been singled out as an international laggard on climate change and energy policy in multiple international fora over the last several years $[7,95,197-201]$. This paper has attempted to demonstrate that Australia's poor overall performance on climate change and energy policy can be directly attributed to the pervasive influence of the fossil fuel and resource extraction industries on Australia's three incumbent political parties. A wide range of overt and covert strategies are routinely deployed by these industries to bolster their influence, which has resulted in at least twenty-four areas of government policy relevant to the decarbonisation of Australian society being stalled or prevented from being implemented. Because the full spectrum of strategies used by these industries are not revealed by discursive analytic methods, the main focus has been on outlining the kinds of critically reflexive scholarship and investigative techniques which can reveal the nature of some of the less well-documented strategies and how they are pursued.

This paper clearly reveals that many tens of billions of dollars are 
being siphoned out of public coffers every year by highly profitable resource and fossil energy industries through direct subsidies, tax concessions, and favourable policy decisions, even when the many billions of dollars in externalities which both industries cost Australia every year are disregarded. During a period in which austerity measures are being reintroduced under COVID, and governments complain they have insufficient financial resources to meet the challenges ahead, the reluctance of Australian governments to curb the ability of these industries to extract more wealth than is due to them makes these complaints seem hollow.

The evidence presented in this paper arguably constitutes a prima facie case for the corporate capture of the country's major political parties with respect to the fossil fuel and resource extraction industries. Theories of economic-elite domination, biased pluralism, para-politics and capital as power provide crucial insights into how a wealthy country like Australia with a strong tradition of liberal democracy can be hijacked by such powerful interests. The hard won democratic reforms of previous generations are being systematically dismantled at the very time we need them as a foundation upon which to build further reforms, and in particular, to accelerate the construction of the low and zero carbon infrastructure that will enable nation states to create millions of new jobs, radically reduce their emissions, and create safer and cleaner environments for all.

Due to considerations of length, this paper has not canvassed the kinds of policy reforms required to curb these activities. Readers are therefore directed to other research which does discuss some of the available options in detail [79,173,189-192,194-196,202-207]. It should nevertheless be clear from the preceding analysis that focusing upon issues such as corporate tax avoidance, post-public-service employment, government accountability, freedom of information, and political lobbying and donations are more likely to bring about better outcomes on climate change and energy policy than a continuing focus on the specific policy levers which have traditionally received the most attention from campaigners and reformers. It is my hope that if we as citizens can better identify the individuals occupying networks of covert influence across multiple portfolio areas within our governments, and for which firms and industries they are working, we are arguably going to be more successful at curbing their influence by raising public awareness of such activities, and crafting appropriate cases for regulatory and legal reform.

\section{Declaration of Competing Interest}

The authors declare that they have no known competing financial interests or personal relationships that could have appeared to influence the work reported in this paper.

\section{Acknowledgements}

I would like to thank Vanessa Bowden, Darrin Durant, Marc Hudson, Phil Johnstone, Sandi Keane, Daniel Nyberg, Joel Rosenzveig, Andy Stirling, Michael West, and the late Stewart Williams for their advice and feedback concerning various drafts of this paper and the associated research.

\section{References}

[1] T. DiMuzio, Capitalizing a future unsustainable: finance, energy and the fate of market civilization, Rev. Int. Polit. Econ. 19 (3) (2012) 363-388.

[2] T. DiMuzio, Carbon Capitalism: Energy, Social Reproduction and World Order, Rowman \& Littlefield, New York, 2015.

[3] A. Malm, Fossil Capital: The Rise of Steam Power and the Roots of Global Warming, Verso, London, 2015.

[4] B. Pittock, Climate Change: Turning Up the Heat, CSIRO Publishing, Canberra, 2005.

[5] IPCC (Intergovernmental Panel on Climate Change), in: IPCC Fourth Assessment Report: Climate Change - Synthesis Report, Cambridge University Press, London, 2007, p. 2007.
[6] R. Heede, Tracing anthropogenic carbon dioxide and methane emissions to fossil fuel and cement producers, 1854-2010, Clim. Change 122 (2014) 229-241.

[7] UNEP (United Nations Environment Program), Emissions Gap Report 2020, UNEP DTU Partnership, Nairobi, 2020.

[8] S. Beder, Global Spin: The Corporate Assault on Environmentalism, second ed. Scribe, Melbourne, 2000.

[9] C. Hamilton, Running From the Storm: The Development of Climate Change Policy in Australia, UNSW Press, Sydney, 2001.

[10] C. Hamilton, Scorcher: The Dirty Politics of Climate Change, Black Inc/Agenda, Melbourne, 2007.

[11] G. Pearse, High and Dry: John Howard, Climate Change and the Selling of Australia's Future, Viking, Camberwell, 2007.

[12] G. Pearse, Quarry Vision: coal, climate change and the end of the resources boom, Q. Essay 33 (2009).

[13] P.J. Jacques, R.E. Dunlap, M. Freeman, The organisation of denial: conservative think tanks and environmental scepticism, Environ. Polit. 17 (3) (2008) 349-385.

[14] A.M. McCright, R.E. Dunlap, Cool dudes: the denial of climate change among conservative while males in the United States, Global Environ. Change 21 (2011) $1163-1172$.

[15] R.J. Brulle, The climate lobby: a sectoral analysis of lobbying spending on climate change in the USA, 2000-2016, Clim. Change (2018) 1-15.

[16] Influence Map, An investor inquiry: how much big oil spends on obstructive climate lobbying, London, 2015.

[17] J. Farrell, Corporate funding and ideological polarization about climate change, Proc. Natl. Acad. Sci. U. S. 113 (1) (2016) 92-97.

[18] G. Supran, N. Oreskes, Assessing ExxonMobil's climate change communications (1977-2014), Environ. Res. Lett. 12 (August) (2017), 1-18, 23.

[19] G. Supran, N. Oreskes, What Exxon Mobil Didn't Say About Climate Change, The New York Times, August 22, 2017.

[20] N. Oreskes, E.M. Conway, Merchants of Doubt: How a Handful of Scientists Obscured the Truth on Issues from Tobacco Smoke to Global Warming, Bloomsbury Press, New York, 2010.

[21] A.M. McCright, R.E. Dunlap, Anti-reflexivity: the American conservative movement's success in undermining climate science and policy, Theory, Cult. Soc. 27 (2-3) (2010) 100-133.

[22] R.J. Brulle, Institutionalizing Delay: foundation funding and the creation of US climate change counter-movement organizations, Clim. Change 122 (4) (2013) 681-694.

[23] J. Farrell, Network structure and influence of the climate change counter movement, Nat. Clim. Change 6 (April) (2016) 370-374.

[24] J. Farrell, The growth of climate change misinformation in US philanthropy: evidence from natural language processing, Environ. Res. Lett. 14 (2019), 034013.

[25] S. Staggenborg, D.S. Meyer, Understanding Countermovements, in: M.C.J. Stoddart, D.B. Tindall, R.E. Dunlap (Eds.), Handbook of Anti-Environmentalism, Edward Elgar, New York (forthcoming).

[26] W.K. Carroll, S. Daub, S. Gunster, Regime of Obstruction: Fossil capitalism and the many facets of climate denial in Canada, in: M.C.J. Stoddart, D.B. Tindall, R.E. Dunlap (Eds.), Handbook of Anti-Environmentalism, Edward Elgar, New York (forthcoming).

[27] S.H. Ali, Neoliberal Governance of Environmentalism in the Post-911 Security Era: The Case of the Pipeline Debates in Canada, in: M.C.J. Stoddart, D.B. Tindall, R.E. Dunlap (Eds.), Handbook of Anti-Environmentalism, Edward Elgar, New York (forthcoming).

[28] P. Doreian, A. Mrvar, The Koch Brothers and their climate change denial social movement, in: M.C.J. Stoddart, D.B. Tindall, R.E. Dunlap (Eds.), Handbook of Anti-Environmentalism, Edward Elgar, New York (forthcoming).

[29] E. Cox, P. Johnstone, A. Stirling, Understanding the intensity of UK policy commitments to nuclear power: the role of perceived imperatives to maintain military nuclear submarine capabilities, Science Policy Research Unit, Occasional Paper Series, SWPS 2016-16, September 2016.

[30] P. Johnstone, A. Stirling, B. Sovacool, Policy mixes for incumbency: exploring the destructive recreation of renewable energy, shale gas 'fracking' and nuclear power in the United Kingdom, Energy Res. Soc. Sci. 33 (2017) 147-162.

[31] P. Johnstone, P. Newell, Sustainability transitions and the state, Environ. Innov. Societal Transitions 27 (2018) 72-82.

[32] A. Stirling, How deep is incumbency? Introducing a 'configuring fields' approach to redistributing and reorienting power in socio-material change, Energy Res. Social Sci. 58 (2019) (2019), 101239.

[33] P. Newell, P. Johnstone, The Political Economy of Incumbency: Fossil Fuel Subsidies in Global and Historical Context, in: J. Skovgaard (Ed.), The Politics of Fossil Fuel Subsidies and their Reform, Cambridge University Press, London, 2018, pp. 66-80.

[34] J.S. Dryzek, The Politics of the Earth: Environmental Discourses, second ed., Oxford University Press, New York, 2005.

[35] B. Warren, P. Christoff, D. Green, Australia's sustainable energy transition: The disjointed politics of decarbonisation, Environ. Innov. Societal Transitions 21 (December) (2016) 1-12.

[36] B.L. Parr, Australian Climate Policy and Diplomacy: Government-Industry Discourses, Routledge, London, 2019.

[37] A. Innes, Corporate state capture in open societies: the emergence of corporate brokerage party systems, East Eur. Polit. Societies 30 (3) (2016) 594-620.

[38] A. Innes, Draining the Swamp: Understanding the Crisis in Mainstream Politics as a Crisis of the State, Slavic Rev., Supplement s1 76 (2017) S30-S38.

[39] E.E. Schattschneider, Political parties and the public interest, Ann. Am. Acad. Polit. Soc. Sci. 280 (1952) 18-26. 
[40] E.E. Schattschneider, The Semisovereign People: A Realist's View of Democracy in America, Holt, Rinehart and Winston, New York, 1960.

[41] D. Adamany, The political science of E. E. Schattschneider: a review essay, Am. Polit. Sci. Rev. 66 (4) (1972) 1321-1335.

[42] C.W. Mills, The Power Elite, Oxford University Press, Oxford, 1956.

[43] G.W. Domhoff, et al., Studying the Power Elite: Fifty Years of Who Rules America? Routledge, New York, 2018.

[44] J. Nitzan, S. Bichler, Capital as Power: A Study of Order and Creorder, Routledge, Abingdon \& New York, 2009.

[45] P.D. Scott, The State, the Deep State, and the Wall Street Overworld, Asia-Pac. J. 12 (10) (2014) 1-28.

[46] D. Scott, The American Deep State: Wall Street, Big Oil, and the Attack on U.S. Democracy, Rowman \& Littlefield, Lanham, 2014.

[47] K. Taft, Oil's Deep State: How the Petroleum Industry Undermines Democracy and Stops Action on Global Warming, Formac Lorimer Books, Halifax, 2018.

[48] R. Birrell, D. Hill, J. Stanley, Quarry Australia? Social and Environmental Perspectives on Managing the Nation's Resources, Oxford University Press, Oxford, 1982.

[49] R. Ray, Government response to the Report of the Senate Standing Committee on Industry, Science and Technology on Gas and Electricity: Combining Efficiency and Greenhouse. Parliament of Australia. Canberra, 1994. Available from: <http ://parlinfo.aph.gov.au/parlInfo/search/display/display.w3p;db=CHAMBER;id =chamber/hansards/1994-03-17/0087; query=Id:\%22chamber/hansards $/ 1994$ 03-17/0079\%22> (accessed 8 August 2021).

[50] G. Parkinson, The Changing Shape of Wind and Solar in Australia's Grid, Renew Economy, 2018.

[51] G. Parkinson, South Australia will be at 100\% Renewables by 2025 - Market Operator, Renew Economy, 2018.

[52] CEC (Clean Energy Council), Clean Energy Australia Report 2021, CEC, Melbourne, 2021.

[53] H. Saddler, National Energy Emissions Audit Report, August/September, The Australia Institute, Canberra, 2020.

[54] B. Mason, The ACT is now running on 100 renewable electricity, SBS News, 1 January, 2020.

[55] Australian Government, National Greenhouse Gas Inventory Quarterly Update: December 2020, Department of Industry, Science, Energy and Resources, Canberra, 2020.

[56] Australian Government, Australia's Emissions Projections 2017, Department of the Environment and Energy, Canberra, 2017.

[57] A. Lucas, Stranded assets, externalities and carbon risk in the Australian coal industry: the case for contraction in a carbon-constrained world, Energy Res. Soc. Sci. 11 (2016) 53-66.

[58] B. Smee, K. Murphy, Australian greenhouse gas emissions fall to lowest level since 1998 under Covid restrictions, The Guardian, 31 August, 2020.

[59] K. Anderson, Duality in climate science, Nat. Geosci. 8 (December) (2015) 898-900.

[60] A. Lucas, Risking the Earth Part 1: reassessing dangerous anthropogenic interference and climate risk in IPCC processes, Clim. Risk Manage. 31 (2021), 100257.

[61] Australian Government, Quarterly Update of Australia's National Greenhouse Gas Inventory: September 2018, Department of the Environment and Energy, Canberra, 2018.

[62] Australian Government, Quarterly Update of Australia's National Greenhouse Gas Inventory: September 2020: Incorporating emissions from the NEM up to December 2020, Department of the Environment and Energy, Canberra, 2020.

[63] L. Byrnes, C. Brown, J. Foster, L.D. Wagner, Australian renewable energy policy: barriers and challenges, Renewable Energy 60 (2013) 711-721.

[64] A. Stock, Australia's Electricity Sector: Ageing, Inefficient and Unprepared, Climate Council of Australia Ltd, Canberra, 2014.

[65] Market Forces, How Your Tax Dollars Subsidise Fossil Fuels, 2020.

[66] . Coady, I. Parry, N-P. Le, B. Shang, Global Fossil Fuel Subsidies Remain Large: An Update Based on Country-Level Estimates, IMF working Paper, International Monetary Fund, 2019.

[67] S. Makhijani, A. Doukas, G20 subsidies to oil, gas and coal production: Australia Country Study, Oil Change International, November, 2015.

[68] K. Fisk, Federal Government announces plan to keep Aussie oil refineries open and improve fuel quality', whichcar.com.au, 17 May, 2021.

[69] C. Gooley, Federal government will spend $\$ 600$ million on new Kurri Kurri gas plant in the NSW Hunter Valley, ABC News, 18 May, 2021.

[70] M. Mazengarb, Cash for Gas and Big Emitters in Another Miserly Budget for Clean Energy and EVs, Renew Economy, 2021.

[71] B. Browne, T. Swann, Money for Nothing, The Australia Institute, Canberra, 2017.

[72] C. Grieve, Super giants funnel billions into fossil fuels, vote down climate push, The Sydney Morning Herald, 13 February, 2020.

[73] A. Morton, Australia is third largest exporter of fossil fuels behind Russia and Saudi Arabia, The Guardian, 18 August, 2019.

[74] C. Chen, A. Randall, The Economic Contest Between Coal Seam Gas Mining and Agriculture on Prime Farmland: It May Be Closer than We Thought, J. Econ, Soc Policy, Special Edition: The Economic and Social Policy Implications of Coal Seam Gas Mining (CSG) Australia 15 (3) (2013) 1-30.

[75] J. Jaganathan, Australia grabs world's biggest LNG exporter crown from Qatar in Nov, Reuters, 10 December, 2018.

[76] DFAT (Department of Foreign Affairs and Trade), in: Country and Commodity Pivot Table to 2019-20, Publications: Trade Statistical Pivot Tables, Australian Government, Canberra, 2006, p. 2020
[77] M. Cunningham, L. Van Uffelen, M. Chambers, The Changing Global Market for Australian Coal, Reserve Bank Australia Bulletin, September, 2019.

[78] P. Yanguas Parra, B. Hare, U. Fuentes Hutfilter, N. Roming, Evaluating the significance of Australia's global fossil fuel carbon footprint, Report prepared by Climate Analytics for the Australian Conservation Foundation, July, 2019.

[79] H. Aulby, Undermining our Democracy: Foreign Corporate Influence through the Australian Mining Lobby, The Australia Institute, Canberra, 2017.

[80] M. West, Corporate lobbying a billion dollar business, Michael West Media, 6 November, 2017.

[81] G. Hutchens, Australia must charge royalties on natural gas or lose billions, says expert, The Guardian, 9 February, 2017.

[82] G. Hutchens, Senate told current tax on oil and gas projects cannot change but future deals should, The Guardian, 3 July, 2017.

[83] E. Bagshaw, Cooking the books on climate change policy, The Sydney Morning Herald, 7 January, 2018.

[84] P. Soos, As planet cooks, Coalition cooks the books on fossil fuel subsidies, Michael West Media, 8 November, 2018.

[85] M. West, Major accounting firms facilitators of global tax avoidance, The New Daily, 12 July, 2016.

[86] M. West, Big Four: government's binge on consultants goes ballistic, Michael West Media, 20 September, 2018.

[87] P. Barratt, Are all those consultancies really necessary?, Pearls and Irritations, 7 March, 2018.

[88] M. West, Glencore tax bill on \$15b income: almost zero, Michael West Media, 27 June, 2014.

[89] M. West, Australia's Top 40 Tax Dodgers 2020: fossil fuels dominate once more, Michael West Media, 31 January, 2020.

[90] R. Campbell, T. Shields, We'll Pay Tax One Day: Submission to Senate Inquiry into Corporate Tax Avoidance, The Australia Institute, Canberra, 2018.

[91] R. Campbell, Petroleum Resource Rent Tax Gas Transfer Pricing Review, The Australia Institute, Canberra, 2019.

[92] R. Campbell, M. Ogge, C. Murray, The Economic Impacts of Unconventional Gas in Western Australia, The Australia Institute, Canberra, 2018.

[93] A. Lucas, Risking the Earth Part 2: Power politics and structural reform of the IPCC and UNFCCC, Clim. Risk Manage. 31 (2021), 100257.

[94] C. Works, Tracking Progress to Net Zero Emissions: National Progress on Reducing Emissions Across the Australian economy and outlook to 2030, Climate Works Australia, Melbourne, 2018.

[95] OECD (Organization for Economic Cooperation and Development), Economic Policy Reforms 2021: Going for Growth: Shaping a Vibrant Economy, OECD Publishing, 2021.

[96] A. Lucas, Confected conflict in the wake of the South Australian blackout: diversionary strategies and policy failure in the Australian energy sector, Energy Res. Soc. Sci. 29 (2017) 149-159.

[97] A. Senate, Retirement of coal fired power stations: Final Report to the Environment and Communications References Committee, Parliament House, Canberra, 2017.

[98] F. Jotzo, S. Mazouz, Brown Coal Exit: A Market Mechanism for Regulated Closure of Highly Emissions Intensive Power Stations, Australian National University, Canberra, 2015.

[99] AEC (Australian Energy Council), Retirement of coal fired power stations: Submission 44, Parliament of Australia, Canberra, 2016.

[100] D. Holmes, The fossil-fuelled economy of Australia's elections, The Conversation, 22 June, 2016.

[101] P. Hannam, "Catastrophic": NSW Greens call for an end to thermal coal mining within a decade, The Sydney Morning Herald, 2 March, 2017.

[102] S. Bishop, Government gives climate-wrecking Adani millions to "attract investment”, Independent Australia, 17 October, 2020.

[103] G. Parkinson, South Australia Takes on Energy Oligopoly in Push for more Renewables, , Renew Economy, 2016.

[104] G. Parkinson, Will Turnbull's Coalition stand up to Australia's energy oligopoly? Renew Economy, 2016.

[105] G. Parkinson, Regulators' Wake Up Call: Fossil Fuel Majors are Gaming Markets, Renew Economy, 2017.

[106] D. Leitch, Too Much Power: The Real Crisis in Australia's Energy Markets, Renew Economy, 2017.

[107] R. Gittins, Consumers left behind by designers of power system, The Sydney Morning Herald, 22 September, 2017.

[108] R. Sims, Shining a light: Australia's gas and electricity affordability problem, Australian Competition and Consumer Commission, 20 September, 2017.

[109] P. Hannam, Turnbull government "knew for years" about network rorts, letters show, The Sydney Morning Herald, 15 May, 2018.

[110] N. Hasham, Watchdog to probe possible $\$ 400$ million power price gouge, The Sydney Morning Herald, 14 May, 2018.

[111] B. Robertson, IEEFA Australia: A gas cartel run amuck', Institute for Energy Economics and Financial Analysis, 13 July, 2018.

[112] B. Robertson, IEEFA op-ed: Gas oligopoly is gouging Australia', Institute for Energy Economics and Financial Analysis, 2018.

[113] B. Robertson, IFEFA Australia: The Glut of Cheap Gas and Lack of Capital to Restart Projects Mean a Gas-led Strategy won’t lead to Economic Recovery, Institute for Energy Economics and Financial Analysis, 2020.

[114] B. Robertson, Gas Cannot Stimulate the Economy, Reduce Emissions, or Provide Cheap Power Australia's National COVID-19 Coordination Commission Is Not Serving the National Interest', Institute for Energy Economics and Financial Analysis, 2020. 
[115] K. Murphy, Labor unveils first electric vehicle policy since Coalition said party was "waging war on the weekend", The Guardian, 30 March, 2021.

[116] G. Parkinson, Morrison Gives Climate the Middle Finger as Australian Emissions Soar over Paris, Renew Economy, 2018.

[117] G. Parkinson, Five Things We Learned this Week (and Tony Abbott didn't) ..., Renew Economy, 2012

[118] B. Toohey, How Australia's energy distributors successfully captured the regulators, The Australian Financial Review, 28 May, 2017.

[119] J. Menadue, New TI Report: rent-seekers and corruption risks in the Australian mining industry, 24 October, 2017.

[120] N. Abjorensen, Watching the industry watchdogs: Australia's regulators are too easily influenced by the business groups they supposedly police, The Sydney Morning Herald, 5 June, 2018.

[121] Influence Map, Gridlock in UK Power Markets: How Big Six capture of the regulatory process poses investor risk, Friends Provident Foundation, London, October, 2018.

[122] G. Parkinson, Coalition Votes to kill Renewables, Encourage New Coal Generation, Renew Economy, 2018.

[123] P. Christoff, Labor's reset on climate and jobs is a political mirage, The Conversation, 30 October, 2019.

[124] G. Goddard, M.A. Farrelly, Just transition management: balancing just outcomes with just processes in Australian renewable energy transitions, Appl. Energy 225 (2018) 110-123.

[125] M. Taylor, Global Warming and Climate Change: What Australia Knew and Buried then Framed a New Reality for the Public, ANU Press, Canberra, 2014.

[126] E. Jackson, Turnbull just showed what happens when "ideology and idiocy" take charge of energy policy, The Guardian, 20 August, 2018.

[127] S. Sengupta, Climate Change Policy Toppled Australia's Leader: Here's What It Means for Others, The New York Times, 24 August, 2018.

[128] C. Wahlquist, "Incredibly worrying": legal fight looms around Australia over clampdown on protest, The Guardian, 6 October, 2019.

[129] M. Wilkinson, The Carbon Club, Allen \& Unwin, Melbourne, 2020.

[130] V. Vivoda, Security in doubt as Australia's aging oil refineries shut down, The Conversation, 27 February, 2012.

[131] D. Hurst, Australia to spend $\$ 94 \mathrm{~m}$ on crude oil stockpile - but will store the fuel in the US, The Guardian, 22 April, 2020.

[132] B. Robertson, IEEFA Update: Australia's Natural-Gas Cartel Is Bleeding Australia, Institute for Energy Economics and Financial Analysis, 2016.

[133] J. Norman, Australia looks to access US fuel reserves to shore up supplies amid Persian Gulf tensions. ABC News, 5 August, 2019.

[134] Productivity Commission, National Water Reform 2020, Commonwealth of Australia, Canberra, 2021.

[135] A. Druce, Anti-mining groups and farmers claim hypocrisy over Pilliga gas well fire rules, The Land, 7 December, 2015.

[136] M. West, Glencore, media battles and the pitfalls of fighting a multinational, Michael West Media, 7 May, 2018.

[137] E. Bagshaw, "Staggering": $\$ 90$ billion lost in resources tax, The Sydney Morning Herald, 12 April, 2018.

[138] E. Bagshaw, Turnbull government's PRRT reforms "worth nothing", says expert The Canberra Times, 27 April, 2018.

[139] D. Gocher, Minerals Council demands "reform" while its members pay little or no tax, Michael West Media, 4 June, 2020.

[140] Influence Map 2020. 'Corporate Lobbying: How Companies Really Impact Progress on Climate', London.

[141] E. Holden, How the oil industry has spent billions to control the climate change conversation, The Guardian, 9 January, 2020.

[142] E. Minter, Pressure builds on Woodside to shed its climate stance; expect AGM fireworks, Michael West Media, 12 April, 2021.

[143] Eurodad, Fifty Shades of Tax Dodging: The EU's Role in Supporting an Unjus Global Tax System, Eurodad, Brussels, 2015.

[144] M. Gilens, B.I. Page, Testing theories of american politics: elites, interest groups, and average citizens, Perspect. Polit. 12 (3) (2014) 564-581.

[145] C. Lindblom, Politics and Markets: The World's Political-Economic Systems, Basic Books, New York, 1977.

[146] H. Stephenson, Cheating on climate change? Australia's challenge to global warming norms, Aust. J. Int. Affairs 63 (2) (2009) 165-186.

[147] M. McDonald, The future of Australian climate politics, Aust. J. Polit. Hist. 59 (3) (2013) 449-456.

[148] M. McDonald, Climate security and economic security: the limits to climate change action in Australia? Int. Polit. 52 (4) (2015) 484-501.

[149] Campaign Against Arms Trade, Issues: Political Influence, Campaign Against Arms Trade, London, 31 March, 2017.

[150] Open Secrets, Revolving Door', Center for Responsive Politics, 2021.

[151] POGO (Project on Government Oversight), SEC Revolving Door Database, Project on Government Oversight, Washington DC, 2021.

[152] Michael West Media, Revolving Doors - Democracy at risk, an ongoing public interest research project, 2021.

[153] J.B. Vidal, M. Draca, C. Fons-Rosen, "Revolving door" lobbyists: The value of political connections in Washington, Vox EU, 28 October, 2011.

[154] J.B. Vidal, M. Draca, C. Fons-Rosen, The Power of K Street: New Research on the Economics of Lobbying, CESifo DICE Report 1, 2011.

[155] L. Mannix, Revolving regulators: How one door opens another in Australia's financial system, The Sydney Morning Herald, 24 July, 2015.

[156] R. Brookes, S. Hughes, Public Servants, Private Paydays: How ministers and mandarins make life after government pay - a Revolving Doors Special, Private Eye, 1-6, 2016.
[157] . Ramiro, The Establishment's Revolving Door: the View from Portugal, Novara Media, 8 March, 2016

[158] C. Murray, P. Frijters, Game of Mates: How favours bleed the nation, Lightning Source, Milton Keynes, 2017

[159] P. Bartlett Quintanilla, P. Cummins-Tripodi (Eds.), Revolving Doors and the Fossil Fuel Industry: Time to tackle conflicts of interest in climate policy-making, The Greens/EFA Group in the European Parliament, May, 2018.

[160] C. Wright, D. Nyberg, Climate Change, Capitalism, and Corporations: Processes of Creative Self-Destruction, Cambridge University Press, Cambridge, 2015.

[161] T. DiMuzio, The plutonomy of the 1\%: dominant ownership and conspicuous consumption in the new gilded age, Millennium: J. Int. Stud. 43 (2) (2015) 492-510.

[162] J. Mikler, The Political Power of Global Corporations, Polity Press, Cambridge, 2018.

[163] G. Pearse, D. McKnight, B. Burton, Big Coal: Australia's Dirtiest Habit, University of New South Wales Press, Sydney, 2013.

[164] W. Bacon, Sceptical Climate Part 1: Media Coverage of Climate Change in Australia, Australian Centre for Independent Journalism, Sydney, 2011.

[165] W. Bacon, Sceptical Climate Part 2: Climate Science in Australian Newspapers, Australian Centre for Independent Journalism, Sydney, 2013.

[166] W. Bacon, C. Nash, Playing the Media Game: The relative (in)visibility of coal industry interests in media reporting of coal as a climate change issue in Australia, Journalism Stud. 13 (2) (2012) 243-258.

[167] A. Lucas, J. Rosenzveig Holland, Revolving Doors: how the fossil fuel lobby has governments ensnared, Michael West Media, 9 February, 2018.9.

[168] W. Bacon, A. Jegan, Lies, Debates and Silences: How News Corp produces climate skepticism in Australia, GetUp, Sydney, 2020.

[169] S. Bichler, J. Nitzan, Growing through Sabotage: Energizing Hierarchical Power, Working Papers on Capital as Power, No. 2017/02, July, 2017.

[170] P. Bachrach, M.S. Baratz, Two faces of power, Am. Polit. Sci. Rev. 56 (4) (1962) 947-952.

[171] R.A. Dahl, The concept of power, Behav. Sci. 2 (3) (1957) 201-215.

[172] D.A. Fuchs, Commanding heights? The strength and fragility of business power in global politics, Millennium: J. Int. Stud. 33 (3) (2005) 771-801.

[173] D. Wood, K. Griffiths, C. Chivers, Who's in the Room? Access and Influence in Australian Politics, September, Grattan Institute, , Melbourne, 2018.

[174] R.M. Alexander, S.W. Mazza, S. Scholz, Measuring rates of return for lobbying expenditures: an empirical analysis under the American jobs creation act, J. Law Polit. 25 (401) (2009)

[175] S. Bagchi, J. Svejnar, Does wealth inequality matter for growth? The effect of billionaire wealth, income distribution, and poverty, J. Comp. Econ. 43 (2015) 505-530.

[176] P. Frijters, G. Foster, Rising inequality: a benign outgrowth of markets or a symptom of cancerous political favours? Aust. Econ. Rev. 48 (1) (2015) 67-75.

[177] G. Pearse, The business response to climate change: case studies of Australian interest groups, PhD dissertation, Australian National University, Canberra, 2005.

[178] A. Clennell, Slips raise queries on greasing the wheels of power, The Sydney Morning Herald, 6 October, 2009.

[179] H. Aston, Charming army with links to party HQs, The Sydney Morning Herald, 6 April, 2013.

[180] P. Cai, Downer joins Lakes Oil as Rinehart board appointee, The Sydney Morning Herald, 1 February, 2013.

[181] C. England, Former Labor resources minister Martin Ferguson to join UCL board', The Advertiser, 17 March, 2014.

[182] P. Manning, Martin Ferguson's revolving door puts energy industry in a spin, The Guardian, 17 June, 2014.

[183] P. Manning, Taylor-made for the job: The new energy minister has an antirenewables pedigree, The Monthly, 30 August, 2018.

[184] A. Davies, CSG industry hires well-connected staffers, The Sydney Morning Herald, 25 May, 2015.

[185] A. Davies, Rio Tinto's coal mine expansion threatens Bulga again, The Sydney Morning Herald, 1 June. 2015.

[186] G. Chan, Nationals elect party president with ties to Shenhua mining company, The Guardian, 13 September, 2015.

[187] B. Corbett, Ian Macfarlane to helm Queensland Resources Council, The Australian Financial Review, 25 September, 2016.

[188] J. Buckingham, The Revolving Door Between Miners and Government, NSW Greens, 27 March, 2015

[189] H. Aulby, M. Ogge, Greasing the Wheels: The Systematic Weaknesses that Allow Undue Influence by Mining Companies on Government - a QLD Case Study, Australian Conservation Foundation/The Australia Institute, Canberra, 2016.

[190] A. Lucas, Revealed: the extent of job-swapping between public servants and fossil fuel lobbyists, The Conversation, 4 March, 2018.

[191] H. Aulby, The Tip of the Iceberg POLITICAL Donations from The mining Industry, The Australia Institute, Canberra, 2017.

[192] H. Aulby, Different Breeds of Watchdog: Designing a Federal Corruption Watchdog with Teeth, The Australia Institute, Canberra, 2018.

[193] M. West, The Usual Suspects: oil and gas majors star in Australian tax heist, Michael West Media, 16 December, 2020.

[194] ACF (Australian Conservation Foundation), Fossil Fuel Money Distorting Democracy, Australian Conservation Foundation, Carlton, 2020.

[195] B. Edwards, Dark Money: The hidden millions in Australia's political finance system, Inquiry into and report on all aspects of the conduct of the 2016 Federal Election and matters related thereto, Submission 81 - Supplementary Submission 1, Parliament of Australia, Canberra, 2017. 
[196] CPI (Centre for Public Integrity), Hidden money in politics: What the AEC disclosures don't tell us, Briefing Paper, February, 2020.

[197] J. Burck, F. Marten, C. Bals, The Climate Change Performance Index: Results 2016, GermanWatch/Climate Action Network Europe, Bonn, 2015.

[198] J. Burck, F. Marten, C. Bals, N. Höhne, The Climate Change Performance Index: Results 2018, GermanWatch/Climate Action Network Europe, Bonn, 2017.

[199] J. Burck, U. Hagen, N. Höhne, L. Nascimento, C. Bals, The Climate Change Performance Index: Results 2020, GermanWatch/Climate Action Network Europe, Bonn, 2019.

[200] J. Sachs, G. Schmidt-Traub, C. Kroll, G. Lafortune, G. Fuller, Sustainable Development Goals Index and Dashboards Report 2018, Bertelsmann Stiftung and Sustainable Development Solutions Network (SDSN), New York, 2018.

[201] J. Sachs, G. Schmidt-Traub, C. Kroll, G. Lafortune, G. Fuller, F. Woelm, Sustainable Development Report 2020: The Sustainable Development Goals and Covid-19, Cambridge University Press, Cambridge, 2020.

[202] G. Appleby, What's the case for a federal ICAC?, ABC News, 10 September, 2014

[203] D. McKeown, Who pays the piper? Rules for Lobbying Governments in Australia, Canada, UK and USA, Parliamentary Library Research Paper Series, 2014-15, Parliament of Australia, Canberra, 2014.
[204] Transparency International, Submission by Transparency International Australia Re: Establishment of a National Integrity Commission, Submission 11 to Select Committee on the Establishment of a National Integrity Commission, Parliament of Australia, Canberra, 20 April, 2016.

[205] C. Lewis, Come Clean. Stopping the arms race in political donations, Think Tank for Social Democracy, John Cain Foundation, Melbourne, June, 2016.

[206] CPI (Centre for Public Integrity), Disclosure of Political Donations and Electoral Expenditure, February, 2020.

[207] B. Collaery, Oil Under Troubled Water: Australia's Timor Sea Intrigue, Melbourne University Press, Carlton, 2020.

Adam Lucas is a senior lecturer in science and technology studies at the University of Wollongong (UOW). His research focuses on the history and sociology of early modern and premodern machine technology, and contemporary climate change and energy policy. $\mathrm{He}$ is particularly interested in processes of innovation and the democratization of technological decision-making. Prior to taking up his current position at UOW, he worked for a number of years as a researcher and policy analyst for the New South Wales Government in The Cabinet Office, State and Regional Development, Aboriginal Affairs and Housing. 